\title{
Using A Mobile-Assisted Language Learning-Based Program on Improving Second Year English Majors' Conversational Academic Acquisition and Autonomy
}

\section{Dr. Dalia Ali Maher Abbass Mohammed}

Lecturer of TEFL Curriculum and Instruction,

Faculty of Education, Minia University

\section{Abstract}

The present study was conducted to investigate the impact of using a program based on mobile-assisted language learning approach (MALL) on improving second-year English majors' conversational academic acquisition and autonomy. The study used the quasiexperimental research design (pre-post control group design). Sixty students enrolled in the second year, English section at the Faculty of Education were randomly assigned to two intact groups: an experimental group and a control group. The students in the experimental group were trained and instructed using a program based on mobile-assisted language learning whereas their counterparts in the control group did not receive such training as they received conventional instruction. Instruments of the study included a mobile device literacy questionnaire, a test of conversational academic acquisition and a scale of autonomy. Analysis of data obtained by students using ( $t$-test, and eta-squared) revealed that the students in the experimental group significantly surpassed their counterparts in the control group in the post-performance on the test of conversational academic acquisition and the scale of autonomy.

Key words: Mobile-Assisted Language Learning, ConversationalAcademic Acquisition, Autonomy.

\section{Introduction}

During the last century, Education has been under gradual changes from being exclusively an agenda at the hands of the elite to a widespread issue at the service of the public. Today knowledge acquisition is no longer confined to the classroom. Classroom education has been replaced by virtual environments in the learning approach through technologies which enhance language communicative competence. Consequently, everyone in each society is

\section{5}

Journal of Arabic Studies in Education \& Psychology(ASEP) 
searching to hunt for knowledge. Thus, a knowledge society is a learning society that provides ample and varied opportunities for knowledge for its citizens.

Since technology aids to facilitate life in all its aspects, it also has its indirect impact to promote lifelong learning (Baleghizadeh and Oladerostam, 2010 and Nordan et al 2010). $52 \%$ of daily learning situations include at least one form of technology use. This coincides with Sharples' 3 C's of education: Construction (building an understanding), Conversation (with the other teachers, peers and selves) and control (of pursuing knowledge) (AbuSae'leek, 2014:471). It has been perceived recently that the application of technology in language learning has transited from desktop to palmtop devices such as mobiles and tablets and thereby the concept of mobile-assisted language learning (MALL) has come to existence (Moghaddads \& Bashirn ,2016).

In the era of globalization, the use of mobile technologies and their apps have satisfied the long-standing desire to make use of technology and multi-media in language learning classrooms. These developments changed the teaching-learning levels to make the pedagogy vivid, natural and interactive. The use of these global technologies in education promotes the level of teaching and motivates the learner in providing information by means of innovative and attractive tasks (Wang, 2014; Al-Zahrani, 2015 and Moghaddads and Bashirn ,2016).

The appropriate use of mobile-related technologies in and outside classrooms facilitates the teaching-learning process, enables teachers to access a wealth of resources to enrich the learning environment with authentic materials suitable for different levels of acquisition and helps the students learn the language better and gain information in depth. However, the application of these types of technology

\section{6}


requires pedagogical guidance from skillful teachers (Al Madani and Allafiajiy, 2014; Lindaman and Nolan, 2015 and Moghaddads and Bashirn ,2016).

Emergence of mobile-assisted language learning (MALL)

Language teaching and learning usually involves the use of some type of technology (Warschaur \& Meskill, 2000). Following the grammar translation method with the focus on grammatical details and translation exercises, teachers used the earliest type of technology, i.e. blackboards. Later on, the use of mechanical drilling depended on overhead projectors and the early software computer programs. With the coming of the audio-lingual approach in the 1970s, the use of audio-taped materials through the language labs was a must for language learners. In the late 1980s and early 1990s, the emergence of the cognitive and sociolinguistic approaches with the focus on engaging the learners with authentic and meaningful materials led to the major shift in the use of technology in classrooms. Some of these technologies were, telecommunications, multimedia simulation software, computer -assisted language learning (CALL), e-mail and web conferencing systems. Other forms of technology include MP3 players, DVD players, multimedia cellular phones and mobile-assisted language learning (MALL) (Baleghizadeh and Oladerostam, 2010 and Lidaman and Nolan, 2015).

MALL is considered a subdivision of CALL according to the latest Horizon report 2012 and 2013 which asserted the educational impact of mobile and tablets computing (Johnson et al.,2012). It's a form of technology-assisted learning which can be used in different modes: face-to-face, distant or online and thus, directed for the process of language learning development (Yang,2013; Yelda, 2013; and Lidaman and Nolan, 2015). 
MALL is different from CALL. CALL sought of exposing the students to learning content in a variety of forms in addition to interactivity (Sanders, 1995), whereas MALL has led to integrate language learning into daily life activities. MALL employs the use of personal and portable devices supporting learning through continuous access and interaction across formal and informal contexts (Kukulaska - Hulme and Shield, 2008). In addition to that, mobile-based learning, unlike computer-assisted learning, ought not to require learners to set up specific time for learning, instead they can learn at any time at any place (Yang,2013; Yelda, 2013 and Lidaman and Nolan, 2015).

MALL is not a substitute for existing learning devices but it serves as extension for learning in a new environment with new capabilities (Andrzewjeweska , 2014). Miangah and Nezarat (2012) confirm that mobile devices are the most effective communication medium among all modern communication devices even than e-mails or chat and consequently can function as effective learning tools. These modern mobile devices that have the capacity of language learning (tablets PC, smartphones, etc.) have nearly eliminated the learning differences between the classroom and home as well as the differences between computers and mobile devices (Lee, 2011). In addition to that, mobile devices have been considered as handheld computers with various functions (Yang, 2013). In addition to the usage for oral communication, mobile devices help users recently to access the internet searching for knowledge, reading, emailing or even shopping as well as facilitating learning independent of time or location away from the classroom. Moreover, Mobile learning enables learners to access information easily and become innovative and problemsolvers (Elfeky and Masadeh, 2016).

\section{8}


Meaning and Nature of Mobile-assisted language learning (MALL)

Mobile learning or m-learning is a subdivision of e-learning further documented by the European initiatives as mlearning or Mobilearn (Chinnery, 2006). MALL refers to any type of learning using mobile technology. MALL focuses on the recent type of technology. Thus, MALL has been associated with mobile devices (Moghaddads and Bashirn ,2016).

MALL is a subcategory of both mobile learning (ML) and computer-assisted language learning (CALL). It is a twoway process which comprises the aid of handheld technology and any other similar portable devices to reduce the inadequacy of learning location with the mobility of general portable devices (Stockwell \& Hubbard, 2013). In MALL, the learner does not need to either be at the classroom or set at a computer to get the learning materials. MALL can be considered an ideal solution to language learning barriers in terms of time and place (Oberg et al., 2012; Andrzewjeweska ,2014; Lidaman and Nolan, 2015; and_Moghaddads and Bashirn ,2016).

Mobile learning allows learning on the move; thus, learning has tapped outside the classroom. Through mobile technology, which includes the use of MP3and MP4 players, cell phones, digital cameras, hand-held computers, data storage devices, iPhone, iPad, etc., learners are enabled to form learning communities in either real or virtual communities by connecting to other resources or other people. Thus, learning becomes, authentic, personalized and ubiquitous (Amer, 2010).

The Categorization for MALL in higher education MALL is considered as a core pedagogical activity within higher education institutions (El Hussien \& Cronje; 2010).

\section{9}

Journal of Arabic Studies in Education \& Psychology(ASEP) 
El-Hussein and Cronje (2010) provide a categorization for mobile learning in higher education environment as follows:

1- Mobility of the technology: Nowadays, technology has been embraced by different mobile devices as smartphones, tablets, PADs, etc. These mobile devices have voice recorder, camera, different multimedia functions. These devices also enable users to access internet anytime and anywhere.

2- Mobility of learners: mobile learning addresses learnercentered activities where learners can exercise control over the learning process, learn not only from their teachers but also from accessing information through their mobile devices in an interactive and collaborative context.

3- Mobility of learning: the mobility of learning through mobile devices is described as seamless learning which implies learning anytime and anywhere through using multiple contexts with various mobile devices.

\section{A framework of MALL}

Stockwell \& Hubbard (2013, pp3:5) address MALL through a framework of three domains relating to both their positive and limited aspects of implementation. Both of these positive and negative aspects of MALL have been widely discussed by other researchers.

1- The physical domain

The mobile devices used in language learning have ranged from MP3/MP4, smart phones, iPads to tablets and laptop computers. The physical nature of these devices relates to their positive aspects concerning their small size, portability, functionality, ubiquity, flexibility, situating of instructional activities, connectivity through creating a shared network, individuality, immediacy, permanency, user-friendliness, accessibility and affordability

\section{0}


(AbuSae'leek, 2014; Andrzewjeweska ,2014; Al-Zahrani, 2015 and Moghaddads and Bashirn ,2016).

Other issues that need to be considered are their small screen size, storage capacity, cost, privacy, battery life, reading difficulty, absence of devices as a keyboard or a mouse, limited multimedia and compatibility due to the difficulty to have it work on all platforms (Lindaman and Nolan, 2015 and Moghaddads and Bashirn ,2016).

2- The pedagogical domain

- The use of mobile devices in the field of language learning should address the affordances of the mobility feature of these devices (e.g. audio/video recording, scanning QR codes, using different platforms (what's app), etc.) and move beyond the activities deigned to either printed or computer-based materials such as faceto-face data exchange and collaboration among learners (Moghaddads and Bashirn ,2016)

- The pull and push mechanisms are other pedagogical features that need to be considered. The pull mechanism relates the process of accessing the learning materials to the learner's responsibility, whereas the push mechanism directs information to the learner in the form of texts through mobile SMS, What's app application, face book, etc.

- The wide range of functionality of mobile devices may not be fully used by learners. The use of mobile devices for different social communication purposes doesn't necessarily entail awareness of using them for learning purposes. Mobile learning happens on the move, so environmental circumstances may distract learners (Viberg \& Gronlund, 2012; Al-Zaharani, 2015 and Lindamad and Nolan, 2015). Moreover, it assumes that learners should assume full responsibility over their learning which young learners may lack 
(Andrzewjeweska ,2014). This means that language learners need pedagogical assistance in the way of using their mobile devices for learning purposes (Al Madani and Allafiajiy, 2014).

\section{3- The psycho- social domain}

Mobile devices are equipped with a wide range of applications installed for the purpose of personal and social communication which may lead learners away from using their mobile devices in learning purposes either in formal or informal contexts. Concerning the use of social media networks in EFL classes, Simpson (2012) points out that the use of Face Book didn't develop Korean students' English language competence or motivation. Similarly, Shih (2013) emphasizes the importance of teacher training on integrating Face Book in language classes, otherwise it would be timeconsuming.

The design principles of ML/MALL

Elias (2011) cited by Stockwell and Hubbard (2013:6) sketches out the following four design principles of ML which relate closely to MALL:

1- Equitability through the delivery of the content in the simplest format.

2- Flexibility through the delivery of the content in small chunks.

3- Tolerance for error through supporting and scaffolding methods.

4- Academic climate through employing the push and pull mechanisms and exchanging quizzes and questions.

The six ecosystems of MALL application in a language classroom

Pegrum (2014) indicates that applying MALL in the classroom employs six ecosystems as follows:

\section{2}


1- The linguistic ecosystem which entails the specific target language structures, forms, skills through the targeted language scales including morphemes, sounds, words, paragraphs, conversations or texts.

2- The acquisitional ecosystem which specifies the process of language acquisition provided through their mobile devices (e.g. input/ output, metalinguistic awareness, etc.).

3- The pedagogical ecosystem that determines the classroom instructions that the used mobile devices apps can fulfill (e.g. giving feedback, carrying out summative assessment, etc.).

4- The technological ecosystem which defines the other technologies that the MALL app depends on (e.g. camera, video, Bluetooth, etc.).

5- The institutional ecosystem that requires the availability of teachers, teaching materials and means of assessment in accordance with the institution system. Thus, technology provides a medium of instruction and learning content as well.

6- The sociocultural ecosystem which tackles the nature of the activities assigned to learners which include individual tasks where learners are given chance to explore the information by themselves as well as opportunities for collaborative activities.

MALL and Language Learning

Recently, mobile devices have been an integral part of our lives and started to be integrated within the field of education. They point out that mobile phones are the most widely used devices in mobile learning projects funded by the European Union (Kukulaska - Hulme and Shield, 2008: 271). Moreover, the increase of network access led to the spread of using mobile devices in supporting language learning.

\section{3}


Mobile learning involves the delivery of learning content to mobile devices. It is generally getting hold of any knowledge or skill and practicing it everywhere at any time by using mobile technology (Alley, 2009 and Jee, 2011). Moreover, this learning can be shared in small synchronous or asynchronous groups (Neh et al., 2008 and Alley, 2009).

MALL is not a substitute for existing learning devices but it serves as an extension for learning in a new environment with new capabilities (Andrzewjeweska ,2014). There is a wide acceptance among all those involved in all streams of learning that the use of mobile devices adds opportunities for learning in and outside classroom environment (AlZaharani, 2015 and Leis et al., 2015). Similarly, Kukulaska - Hulme, Norris and Donohue (2015: 8) argue that mobile learning facilitates this through enhancing connections between people, between the place where language is used and the other where language is learned together with the features of mobile devices that enable users to create content and share it with others. In addition, the spread of smartphones with their various apps provided language learners with suitable platforms for informal and individualized ubiquitous learning anywhere at any time.

Weng and Chen (2015) outlined the positive factors that led to the popularity of using mobile devices (especially smartphones) in English language learning and teaching as follows:

1- Four A's (Anywhere, Anytime, Anyway and Achievement).

2- R.A.I.L. (Real-Person Pronunciation, Adaptive Testing, Instant Translation, Language Drills).

3- S.I.D.E. (Supplementary, Interesting, Dual PurposeEffortless). 
It has also been argued that mobile learning can be implemented in different fields of language leaching and learning; i.e. listening, speaking, reading, writing, grammar, pronunciation, conversation, etc. (Stockwell and Hubbard, 2013 and Mohammadi and Safdai, 2015). Collaborative listening and speaking and web-based collaborative activities could be well supported through mobile devices which enable learners to view thinking and learning as tangible (Leis et al., 2015).

\section{MALL and Learning autonomy}

The move away from teachers, textbooks and language labs and towards mobile learning represents a shift of authority from the teacher to the students as the students are taking more responsibility of their learning and the manner of better exploiting their free time (Mitra, 2005 and Kukulaska - Hulme, 2009). Mobile technologies are potential means for delivering content through various means of multimedia leading to learners' efficacy, agency, autonomy and thus successful lifelong learning (Amer, 2010; Mohammadi and Safdai, 2015 and Sato et al.,2015).

Levey and Kennedy (2005) affirmed the effective impacts of using mobile technology through the literature in developing language learning, though they pointed out that the basic notion behind some applications of mobile technology sound to be similar to the concept of web 1.0. This means that there was not any kind of virtually usercreated or user-centered. Since the introduction of the term web 2.0 by Tim O' Reilly in 2004, the term mobile 2.0 was used to signify the technological features of web 2.0 (Wang $\&$ Heffernan, 2009). The main features of web 2.0 are usercreated and collaborative content. Consequently, the new approach to MALL would be reflecting the main features of web 2.0 technology.

\section{5}


The use of mobile devices would allow learners to access authentic resources and search for information and resources fostering the skills of autonomous learning (Sato et al., 2015). It is like a personal or self-learning process for students who are accustomed to take independent decisions concerning their learning process and those who are aware of the possibility of taking responsibility for their learning and learning progress. Mobile devices make learning real, can be retained easily and lead to students' motive for selflearning, control the learning process and progress to individual pace based on individual cognitive state in a nonclassroom environment (Amer, 2010 and Andrzewjeweska ,2014).

\section{Context of the problem}

It is noticeable that most EFL courses used in our national institutions are geared towards rote learning and the practice of the language that is found in examinations rather than using authentic or meaningful activities for the students to learn all the language skills. In addition to that, it is commonly noticed that this rote learning and examinationoriented approach to teaching and learning leads to learners' low proficiency in the language.

As a faculty staff member, it is natural to find those students with limited repertoire of vocabulary feel less confident when conducting conversation in English. More specifically, that those students who fail to use the correct grammatical structures as well as selecting the appropriate expressions during their communication show unwillingness towards communication in the target language.

To be more specific, informal interviews were conducted with freshmen and sophomores at the English section at the Faculty of Education to elicit their opinions about the learning content, materials and activities used. The

\section{6}


information elicited showed the gap between learners' language needs and teachers' teaching methods and materials. Moreover, they asked for different materials than printed textbooks.

Asking the same students about their use of technology, especially mobile devices, for learning purposes revealed that they can share and learn from videos on social media which included words, sounds with images full of cultural elements. This is addressed by Menezes (2011), pointing out that in the process of learning, learners' concept about language learning should be considered.

The researcher thought of adapting some sort of multimedia technology to fulfill learners' language needs. Reviewing the literature of related studies emphasizes the impact of using multimedia technology as videos, cartoons or any other TV programs on fostering the different aspects of language learning; vocabulary, structure, language expressions and any other language skills (Lin, 2012 and Wang, 2014). In addition to that, allowing the learners to watch how the native persons use their English language naturally would enhance their conversational skills and leading them afterwards to create their own authentic conversations on the basis of the different scenarios in the videos (Wang, 2014). Moreover, language learners must keep themselves busy with the language between the lessons as well as in the lessons if improvements are needed (Kukulaska - Hulme, Norris and Donohue,2015).

\section{Review of the literature}

There is a wide acceptance among all those involved in all streams of learning that the use of mobile devices adds opportunities for learning in and outside classroom environment (Stockwell and Hubbard,2013 and Leis et al. ,2015). Consequently, research has shed light on the 
potential of the use of mobile technology on the improvement of language skills.

- Studies focus on the use of MALL for developing conversation:

Mobile application for language learning project (2009) investigated the students' use of mobile technology as a tool to interact with a computer for conducting a conversation in Indonesian. The students participated in the project responded positively to the manner the project improved their Indonesian listening and speaking skills. As for the teachers, they reported that the incorporation of the MALL project was easy into their teaching plans and led to the improvement of both student learning outcomes and language learning skills. Recently, Elfeky and Masadeh (2016) showed that mobile learning significantly affected English language students' academic achievements as well as their conversational skills.

- Studies focus on using MALL outside the classroom and thus fostering autonomy:

Petersen and Divitini (2004) combine features form the mobility of learners with that of mobile devices. They design an activity in which language learners who visit a country resembling the target culture could use the technology of their mobile devices to share this knowledge with other learners at home. They would create knowledge that either satisfy their co-learners' demands for specific information or address the relevant needs of their learning community. Thus, learners would be encouraged to be creators of authentic knowledge and develop their learning autonomy.

Baleghizadeh and Oladerostam (2010) affirmed that engaging pre-intermediate Iranian female students in designed fluency-based activities through using their mobile

\section{8}


phone enabled them to record their voices, analyze their grammatical mistakes, correct them and learn grammar accurately. Leis et al. (2015) emphasized the point that encouraging the students to use their mobile devices inside the classroom for fulfilling tasks motivate them to use these devices for more study in their free time, develop better study habits, improve their English proficiency and thus fostering their language autonomy. Similarly, Sato et al. (2015) affirmed the impact of using mobile devices for facilitating the recall of L2 phrases used in academic writing which leads to successful L2 writing and development of autonomous learning skills.

Fommamai and Hedyati (2016) conducted a study where the students were asked to use their mobile devices to take photos, create materials about English idioms and share them online for their peers to comment on. The students were then given opportunities to generate their learning resources, be actively engaged in their learning context, bridge the gap between in-class and out- of class activities and thus support their learning autonomy.

- Studies focus on using the mobile devices for driving different linguistic output from students classified according to the different language skills:

The studies conducted by Lan, Sung and Chung (2007), Zahng et al. (2011) and Al Qasim and Al Fadda (2013) indicated that mobile devices are effective tools for improving listening comprehension and language learning motivation. Rahimi and Solymani (2015) and Moghaddad and Bashirnzad (2016) confirmed the ability of mobile devices to reduce listening anxiety and increase the fluency of speaking skills. Similarly, Mohammadi and Safdari (2015) examined the impact of online mobile-task based activities on improving Iranian intermediate English as a

\section{9}


foreign language (EFL) learners' speaking skill. The results showed that the students' interactive autonomous speaking ability was significantly developed in comparison with their counterparts in the non-interactive group.

Balighzadeh and Oladrostam (2010) and Guerrero and Collazos (2010) pointed out that mobile learning activities are effective in fostering learners' grammatical skills and autonomy in addition to developing their self-editing skills in writing.

The results of Chen and Hsu (2008) revealed the possibility of using the system of m-learning to suggest new reading articles for L2 learners on the basis of their language level and consequently learn unfamiliar vocabulary. Similarly, Wang and Smith (2013), Sato et al. (2013), Khubryai and Narafshan (2016) pointed out that there was a common preference among learners to receive reading materials on their mobile devices than on papers due to their portability and accessibility leading to improved reading and grammar skills. Recently, the study of Hazaerea and Alzubi (2016) revealed that mobile- supported cooperative reading activity enhanced the Saudi learners ' reading comprehension, their motivation for language learning.

According to Stockwell (2008), Sylevster and Greenidge (2009) the use of digital tools decreases the students' struggle with traditional texts and leads them to feel more comfortable and think strategically before writing. Similarly, Leis et al. (2014) and Shah et al. (2014) pointed out that MALL helps learners to develop their writing skills without worrying about time or place.

Reinders et al. (2010) pointed out that the use of visual materials as a sensory input through mobile devices to language learners would orient them with the cultural

\section{0}


aspects of the foreign language, foster listening and speaking skills, aid in pronunciation and recall of the presented language forms, and duplicate situation which the foreign language classroom may not produce. Additionally, the use of mobile phones has significantly affected learners from different perspectives, i.e. their attitudes (Jabbour, 2013), academic achievement and self-regulation (Bidakie et al., 2013), improvement of English for multiple purposes; studying at universities, getting or even securing a job as well as improving the English language (research project, 2013-2014), EFL learners' English language proficiency and speaking habits( Wang, 2014), their academic achievement and metacognition awareness (Dos, 2014), general English learning (Muhammed, 2014) and ESP and education (Simonova, 2015).

- Studies address the impact of using various applications of mobile devices

Research has supported the utility of using mobile apps in fostering different aspects of language teaching and learning. Thoronton and Houser (2005) taught short English lessons by sending them to their students' mails using their mobile phones. Ogata et al. (2008) affirmed the students' success in integrating the classroom knowledge with their real needs in their actual daily life situations using mobile devices with GPS feature. Rivers (2009) asked Japanese learners of English to scan QR codes graphics through their mobile devices to link automatically to online information and complete exchange tasks. Amer (2010) explored the way four groups of English learners used a mobile device application designed by the researcher (idiomobile) to learn idiomatic expressions and collocations. Results of the study affirmed the learners' positive attitude towards the application in enhancing learning longer idiomatic expressions in particular and towards the use of mobile

\section{1}


technology in language learning in general. Sandberg, Maris and de Geus (2011) used the GPS capabilities in their Dutch students' mobile phones to learn English vocabulary. They were asked to negotiate their way around the zoo and completed a series of games based on the locations of the animals in the zoo. Park and Yang (2012) and Godwin and Johns (2010 and 2011) used Supermemo, SRS apps for vocabulary learning. Al-Zahari (2015) used (What's App) to provide learners with additional learning activities as well as exploring learners' collaboration in their listening and speaking skills.

Moreover, investigating the impact of using the mobile apps as tools for language learning revealed the extension of a learning environment beyond the classroom (Kennedy \& Levy, 2008), the repeated practice (kukulaska- Hulumne, 2012), the opportunity for personalized learning through fulfilling tasks easily, habitually and spontaneously (Steel, 2012), the positive perception of the students towards using it in English learning (White \& Mills, 2014), the opportunity for making language learning more fun (Stockwell, 2008 ; Leis, 2014 and Lindaman and Nolan, 2015) and the increased motivation for ubiquitous learning (Zou \& Li, 2015). Thus, mobile apps enable learners to achieve better learning outcomes.

Some teachers gave vocabulary instructions via SMS for Italian students in Australia (Livy \& Kennedy, 2005). In Japan, Thornton and Houser (2005) affirmed the utility of mobile phones on helping foreign language learners to learn more effectively and that text messages were very helpful in teaching and learning vocabulary. Similarly, Levy and Kennedy (2005) and Kennedy and Levy (2008) assured the success of the SMS technique in Italian language learning as well as the participants' positive attitude towards receiving text messages. Similarly, Lu (2008) and Zhange et al.

\section{2}


(2011) declared that mobile users surpassed paper-based learners concerning vocabulary gain. Similarly, Motallebezadeh and Ganjali (2011) found out that Iranian students who used mobile SMS achieved better scores than the students in the control group concerning the postperformance in vocabulary retention and reading comprehension. Winet (2016) showed that using SMS in an ESL class led to the increase of the students' motivation, reflection, output and the quality of their learning.

Cooney and Keogh (2007) used voice-input rather than textinput through mobile phones for formal learners' assessment. Sad (2008) designed a project- based video task, that combines drama, technology and CLT, where students recorded their work using their mobile phones to get support, collaboration and feedback from their peers which led to learners' sense of achievement.

Different scholars investigated the impact of using mobile blogging on English language learner and found out that they are effective tools for assessing learners' performance outcomes and building mutual interaction between instructors and their students (Hus et al., 2008), facilitating interaction and developing a sense of community among foreign students studied abroad in Spain (Qomas - Quinn et al., 2009), the practicality of mobile technology and mobile blogs of building community in a French class even when the communities were physically separated (Petersen et al., 2009) and in encouraging and sharing the teacher trainees' reflections on teaching (Wishart, 2000). Moreover, Shao (2010) pointed out that mobile group blog helped Chinese students who were newly comers to Britain to understand the authentic target culture and language use.

- Studies address mobile learning through different platforms

\section{3}


FallahKhair et al. (2007) described an approach of developing a cross-platform through using mobile phones and television programs for informal language learning which in turn led to fostering language learners' repertoire of the target language, culture and context of use. Lan et al. (2007) used Skype platform with the students to support interaction and collaboration through being asked to read aloud, listen to each other and receive feedback through pronunciation errors being pointed out on a screen by peer helpers. Hill, Song and West (2009) found that the availability of a model in web-based learning environments (online discussions) engaged the learners more effectively. Leis et al. (2014) used a social networking system (SNS) to encourage EFL students to continue their discussions out of class as a part of a foreign cultures class. The results suggested that the students with linguistic self-confidence and high learning motivation showed positive attitudes towards participation in the system in English for academic purposes rather than the other students. Leow et al. (2014) developed a mobile-assisted second language learning (MASLL) framework to help L2 teachers and learners identify the core of the cognitive process of L2 learning with the help of smartphones with internet access that were used in developing a mobile chat room environment for L2 learning. Moreover, Al-Zaharani (2015) asserted that using mobile devices for conducting online discussions through web-based platforms (Face Book) with a more knowledgeable person (e.g. teacher) led to a more positive and engaging learning process.

The results of the previous studies that employ the technology of mobile devices confirm its utility in enhancing learners' second language acquisition. However, the majority of these studies addressed primarily the development of learners' vocabulary acquisition, listening 
and speaking skills and general language acquisition. Moreover, the attitude towards language acquisition and the intention of the use of mobile devices. Thus, this gives the present study a place in the MALL research review as very limited studies tackled the impact of MALL in improving the learners' conversational academic acquisition and autonomy.

\section{Statement of the Problem}

English conversations instruction that is offered nationally to EFL students generally and to English majors at the Faculties of Education is based on rote learning with very few opportunities for practice and use of authentic materials and activities. Consequently, most language learners suffer from low proficiency in their language. For improving the language learners' knowledge and use of conversations, the teaching tools, materials and activities should closely address the learners' needs. Learners should be equipped with the technical skills that suit the net generation of digital citizens. Thus, this study is an attempt to investigate the use of mobile-assisted language learning-based program on improving second year English majors' conversational academic acquisition and their autonomy.

\section{Questions of the study}

The present study attempted to answer the following questions:

1. What is the effect of using a mobile-assisted language learning based-program on improving second-year English majors' conversational academic acquisition?

2. What is the effect of using a mobile-assisted language learning based-program on improving second-year English majors' autonomy?

\section{Objectives of the study}

The current study attempted to identify:

\section{5}


1- the effect of using a mobile-assisted language learning based-program on improving second-year English majors' conversational academic acquisition.

2- the effect of using a mobile-assisted language learning based-program on improving second-year English majors' autonomy.

\section{Hypotheses of the study}

The present study attempted to test the following hypotheses:

1- There would be a statistically significant difference between mean scores obtained by the students of the experimental and the control groups on the postperformance of the test of conversational academic acquisition (favoring the experimental group).

2- There would be a statistically significant difference between mean values obtained by the students of the experimental and the control groups on the postperformance of the scale of autonomy (favoring the experimental group).

\section{Rationale of the study}

\section{The hypotheses}

All the hypotheses of the study were stated on the basis of the literature reviewed which showed that a great number of studies recommended the use of MALL in fostering both the cognitive and psychological domains of learning. More specifically, Thoronton and Houser, 2005; Balighzadeh and Oladrostam, 2010; Zhange et al., 2011; Sato et al., 2013 and Wang and Smith, 2013 addressed the impact of using recent technology on developing learners' vocabulary retention, grammar, listening and general language learning. Thus, it is expected that integrating MALL with a conversation course would enhance learners' conversational academic acquisition.

\section{6}


Similarly, Guerrero and Collazos, 2010; Sato et., 2015 and Fommamai and Hedyati, 2016 confirmed that instructing learners using technology inside and outside the class would increase their autonomy. Thus, it is expected that using MALL would increase the learners' autonomy.

\section{The theoretical rationale}

This study is rooted in foreign language theories as follows:

a- The communicative language approach (CLT)

Communication, meaningfulness, contextualization are the three primary intertwined principles of CLT, upon which the present study has been based, are synthesized by Savignon (2000) cited in Wang (2014:13).

b- Behaviorism

The relationship of mobile learning to Behaviourism is clarified through its main principle which relates each stimulus to a specific response (Smith \& Ragan, 2005). According to mobile learning, this principle is applied through the delivered content to mobile devices as stimuli and the students' rehearsal, answers to quizzes, feedback and reflection as responses.

c- Cognitive Approach

The relationship between mobile learning and cognitive approach is simplified through the use of the available multimedia means of mobile devices. By providing the learning materials to learners in advance, this multimedia means enable learners to reorganize their cognitive structures to process, store and then retain the information at anytime and anywhere (Good and Prophy, 1990).

d- Constructivism

Bates and Bates (2015) claimed that constructivism is based on the concept that knowledge is essentially subjective in

\section{7}

Journal of Arabic Studies in Education \& Psychology(ASEP) 
nature and that people construct new knowledge rather than simply acquiring it through memorization or transmission from those who know to who don't know. Social constructivism, they added, stresses the idea that learning happens better through social interaction, collaboration and co-instruction of knowledge. Mobile devices are very supportive tools since they enable learners to either identify or create knowledge then share this knowledge.

\section{e- Contextual Learning Theory}

Mobile learning relates to contextual learning theory on the basis of the technology available in mobile phones that can bring real life to learners at their own place (De Jong et al., 2008). Thus, learners can administer the contextual learning content, browse and restore it whenever and wherever they wish

\section{f- Situated Learning Theory}

Mobile learning is linked to the situated learning theory through the use of social communication platforms and networking means available through mobile phones. These means will aid in creating authentic language contexts through which new knowledge could be delivered and learners would be given ample opportunities to simulate real life situations (Brown et al. 1998).

\section{Significance of the study}

Research has shed light on the potential of the use of mobile technology on the improvement of language skills (Stockwell \&_Hubbard, 2013). Most of MALL studies addressed vocabulary learning and speaking skills while the other language aspects as grammar, listening, conversation or writing were less represented (Amer, 2010). There are hardly any studies, to the best of the researcher's knowledge, that examined the use of MALL for improving

\section{8}


English majors' conversational academic acquisition and learning. This gives the study an importance in the domain of teacher education and TEFL.

More specifically, the present study is, hopefully, expected to:

1. Bridge the gap between in-class and out- of class learning, formal and informal environments in addition to the gap between the use of mobile devices for social communication and academic purposes.

2. Improve both the academic knowledge and use of English conversations through mobile technology not only for adult EFL language learners but for all levels of any language learners.

3. Improve the use of mobile devices for accessing authentic language resources, searching for information, delivering content through various means of multimedia and thus fostering learning autonomy.

4. Aid language teachers and institutions through the ideas offered in developing their language learning outcomes, lesson planning skills, assessment and evaluation procedures reflecting their pedagogical wisdom, class and language dynamics.

5. Enable language learners through adapting the framework presented in this study through the use of technological mobile devices to have authentic and meaningful opportunities for language learning.

6. Improve language learners' technical skills, problemsolving together with their autonomy as important $21^{\text {st }}$ century skills.

7. Raise the learners' academic and cultural language knowledge as well as their interpersonal communication skills. 
8. Serve the need of textbook designers for diversify pedagogical strategies and language learning activities.

9. Afford new dynamics for collaborative learning in synchronous or asynchronous groups.

10.Engage learners in regular self-reflection in the completion of learning assignments for fostering autonomy through using mobile technologies.

\section{Delimitations of the study}

1- The study was delimited to second year English majors enrolled at the Faculty of Education, Minia University. The mobile-assisted language learning -based program is sought to help these learners to better improve both their conversational academic acquisition in addition to their autonomy. Thus, they are expected to purse the other conversion courses in their institution or at any other place with more improved academic and technical skills.

2- There is no balance between male and female second year English majors in both the experimental and the control groups. This is due to the sex ratio of the population of second year English majors.

3 - The introductory section of the study program with its technical and pedagogical skills was determined only after participants' response on the needs-analysis survey of mobile literacy.

4- The conversation topics included in the program were determined on the basis of learners' needs. A list of some common conversation topics was administered to second year English majors to select what they need to study. Suggestions for other topics were allowed. The chosen conversation topics are:

a- Job interviews

b- Social groups

c- Getting around

d- Phone conversations

e- Hopes \& Wishes.

\section{0}


5- The video clips uploaded to the closed face book group account are restricted to either those uploaded by the researcher or those suggested as further resources due to cultural differences.

6- The mobile applications employed in the study are only those that take the advantage of the features of mobile devices and could not be replicated using pen and paper (video/ audio recording).

7- The elements of the conversation topics are limited to the academic knowledge and the written form of the use of the conversations tackled. This is due to the researcher's intention to help learners improve the basic skills of the conversation upon which they can improve the other skills on their own. Also, the relationship between MALL and speaking have been demonstrated greatly through the literature.

\section{Definitions of terms}

\section{Mobile- assisted language learning (MALL)}

- Kukulska-Hulme (2005) and Naismith et al. (2004) define MALL as language learning enabled by the mobility of the learner and location, and portability of handheld devices

- Kukulaska - Hulme and Shield (2008) define MALL as the use of personal and portable devices supporting learning through continuous access and interaction across formal and informal contexts.

- In the present study, the researcher adopted the first definition by Kukulska-Hulme (2005) and Naismith et al. (2004).

\section{Autonomy}

- Benson (2001) defines autonomy as the capacity to take control of one's own learning.

- In the present study, autonomy is defined as the active involvement in the learning process that enables the

\section{1}


learner to function effectively and independently in making learning decisions in formal and informal situations.

\section{Language acquisition}

- In alleydog. Online dictionary, language acquisition is defined as the process and learning curve of skills by which a child acquires language. This set of skills contains the ability to perceive and comprehend language, as well as the ability to produce and use words and sentences to communicate.

\section{Conversational academic acquisition}

- In the present study, conversational academic acquisition is defined as

The possession of formal and informal linguistic components of conversations which include vocabulary, linguistic expressions and grammar to produce words and sentences to communicate successfully.

\section{Methodology}

\section{Research Design}

The present study utilized the quasi-experimental research design. The pre-post control group design (Hatch and Farhady, 1982) was used in designing and conducting the study. An experimental group and a control group were exposed to pre and post means of getting data. The experimental group only was instructed and trained using a program based on mobile-assisted language learning while the control group did not receive such training.

\section{The Pilot Study}

The pilot sample of the study consisted of sixty (60) male and female English majors enrolled in second year at the Faculty of Education, Minia University in the academic year

\section{2}

Journal of Arabic Studies in Education \& Psychology(ASEP) 
$2015 / 2016$. The pilot study lasted for fifteen days before the treatment and helped in determining the validity and reliability of the study tools.

\section{Participants of the Study}

The main sample of the study consisted of sixty English majors enrolled in the second year at the Faculty of Education, Minia University in the academic year 2015/2016. They were randomly divided into two equal intact groups; experimental and control and were of the same age level and the same grade level.

\section{Instructor}

The researcher taught only the experimental group by herself while the control group was taught by a lecturer from the Faculty of Arts. This was done to avoid contamination of the procedures of teaching the control group and to keep the two groups intact.

\section{Instructional design of the study}

The experimental treatment: the participants in the experimental group went through the following procedures:

a- A questionnaire of mobile-literacy was applied to enable the researcher to be acquainted with the types and facilities of the participants' mobile devices. In addition to that, there was a need to identify their comfort level with technology, their collaboration, the degree of their engagement in language learning using their mobile devices, the way and the purposes they use their mobile phones for.

b- A learning community platform (face book account) was created to help the students interact and collaborate together, share knowledge, ask questions related to language learning. conduct language teaching, initiate inquiries about language use, foster interpersonal communication and students' collaboration.

\section{3}


c- They were instructed using the MALL-based program in which the framework of mobile-assisted language teaching and learning proposed by Kukulaska - Hulme, Norris and Donohue in 2015 was adapted. The framework is based on four spheres; teacher wisdom, device features, learner mobilities and language dynamics which are linked with four interconnected concepts; outcomes, inquiry, rehearsal and reflection (Kukulaska - Hulme, Norris and Donohue, 2015: 8).

The four spheres of the framework revolve around the following concepts:

1- Teacher wisdom: focuses mainly on the teacher's pedagogical role and work experience.

2- Device features: make exploitation of mobile technology enabling teachers and their learners to communicate, collaborate and share academic and professional language knowledge and skills.

3- Learner mobilities: include the time and locations of learning with the learners' personal goals responsible for autonomous learning beyond the classroom.

4- Language dynamics: make use of the available technological platforms (e.g. Face Book) to initiate inquiries about the target language together with facilitating interpersonal communication, reflection and language practice.

The four linking concepts describe the following focusing ideas:

1- Outcomes: involve the consideration of language learning products as a result of active participation in teaching and learning activities using the mobile devices technology.

2- Inquiry: is based on making use of mobile devices technology to pose questions, seek answers and share needed language knowledge.

\section{4}


3-Rehearsal: deals with the teacher's role of addressing learners' language gaps and offering supportive learning environment for facilitating learners' language rehearsal and practice as well as receiving helpful feedback. Through mobile technology, language rehearsal and practice can be enhanced both inside and outside the classroom environment.

4- Reflection: revolves around teacher's modelling of the presented language forms, providing feedback and enabling learners' reflection on their learning with the use of mobile devices.

d- The adaptation of the framework through the teaching sessions has done as follows:

1- Teacher wisdom:

1.1. The researcher chooses an appropriate video clip that introduces one of the conversation topics the students chose to be discussed.

1.2. The researcher shares the video clip, through the group Face Book account; "English Teacher", which was a closed group. This happens at least a week before the coming lecture beyond the classroom environment to ensure that all the members would have a chance to download or share it.

1.3. The researcher prepares some personalized and authentic tasks that use the assigned target language forms presented in the video but are more meaningful and motivating for the learners. Some of the tasks would be done at the class and others would be done beyond the classroom.

2- Learners' mobilities:

2.1. The time space between sharing the video and meeting the students physically in class is meant to help learners develop virtual interpersonal communication skills among themselves and the

\section{5}


researcher. They are encouraged to initiate inquiries and exchange questions and answers concerning the presented language forms beyond the classroom environment as well as receiving supportive feedback through their close group Face Book account.

2.2. The learners are also provided with the time appropriate for reflecting on their learning experiences, comparing L1 with L2 with the help of their mobile devices and developing their learning autonomy as they can take personal decisions about time of pausing, rewinding or taking notes of every new word or structure at their own pace.

2.3. Learners would create personalized and authentic artefacts for their learning (e.g. extended personal conversations, posters, recordings, photos, tags, etc.).

3. Device features:

3.1. The learners are asked to use their mobile devices to download the videos and search for any needed knowledge where they would have internet access and keep it on their devices till they meet in their classroom.

3.2. The learners are encouraged to collaborate together by sharing the video with those who couldn't download it for any reason; i.e. internet deficiencies or any other problem.

3.3. During the teaching sessions they are asked to use their devices for taking photos of the researcher' $\mathrm{s}$ presented material on the board or through posters or having screen shots of any important knowledge. They can also use the recording feature of the device to record their own or peers' rehearsal of the presented language forms.

\section{6}


4. Language dynamics:

4.1. Beyond the classroom environment, the learners are asked to watch the video, reflect on their language learning and share any inquiries through their closed Face Book group.

4.2. During the teaching session, the researcher would address gaps in the learners' knowledge of the presented conversation. The researcher would model and scaffold the needed lexis, grammar, formal and informal language forms.

4.3. In their class, the learners would have a chance to be engaged in language activities; role play, gallery walk, ..., to practice the language forms presented through the video and followed by any needed feedback from the researcher.

- The control treatment: students in the control group received instruction on the conversation course using the conventional way with no mobile devices' intervention.

\section{Variables of the Study}

- The Independent Variable

The use of a mobile-assisted language learning (MALL) program.

- The Dependent Variables

Level of conversational academic acquisition.

Level of autonomy

- The Control Variables

Age: the age level of the participants ranges from 17 to 18 .

Linguistic background: as all the participants studied English at public schools in Minia Governerate.

\section{Instruments of the study}

1- A needs-analysis survey for mobile devices- literacy.

- Objectives of the survey:

Identifying the basic knowledge and the main technical and pedagogical skills that are highly needed by second- year English majors in the field of MALL.

\section{7}


- Construction of the survey:

a- Reviewing the literature related to the domain of MALL.

b- Stating the objective of the survey.

c- Designing a preliminary survey. It consists of three variables with 17 multiple-choice item and one openended item.

d- Evaluating the preliminary form of the survey by a jury of TEFL experts.

- Validity of the survey:

A jury of 8 TEFL experts approved the face validity of the survey, its suitability and appropriacy for the study sample.

- Administration of the survey:

The survey was administered to the students of the experimental group to determine the knowledge, technical and pedagogical skills they would need at the introductory stage of the study.

- Results:

Analyzing the data obtained revealed the possession of mobile devices of all of the students of the experimental group. In addition, there was a common familiarity among the students with the different apps of mobile devices. However, their use of these apps was greatly directed towards social purposes rather than academic ones. Table (1) presents the percentage of the students' choice of the items of the survey.

\section{2- A conversational academic acquisition test:}

- Objectives of the test:

A conversational academic acquisition test was designed by the researcher for second-year English majors to asses both their academic knowledge and communicative use of

\section{8}




\section{Number 71, Part 2, March, 2016}

Table (1)Variable/response distributionOf the Needs-analysis survey of Mobile-devices literacy

\begin{tabular}{|c|c|c|c|c|c|c|c|}
\hline $\begin{array}{l}\text { The } \\
\text { Variable }\end{array}$ & $\begin{array}{l}\text { Correspondi } \\
\text { ng number of } \\
\text { statements }\end{array}$ & \multicolumn{5}{|c|}{ Variable/ Response distribution } & $\begin{array}{l}\text { Total } \\
\text { number } \\
(\mathrm{N})\end{array}$ \\
\hline \multicolumn{8}{|l|}{$\begin{array}{l}\text { Background } \\
\text { knowledge }\end{array}$} \\
\hline & 1 & \multicolumn{2}{|c|}{ Yes } & \multicolumn{2}{|l|}{$100 \%$} & & 30 \\
\hline & 2 & \multicolumn{2}{|c|}{$\begin{array}{l}\text { Smartphones } \\
\text { Tablets } \\
\text { iPad }\end{array}$} & \multicolumn{2}{|c|}{$\begin{array}{c}70 \% \\
30 \% \\
0 \% \\
\end{array}$} & & \\
\hline & 3 & \multicolumn{2}{|c|}{ English } & \multicolumn{2}{|c|}{$100 \%$} & & \\
\hline & 10 & \multicolumn{2}{|c|}{$\begin{array}{l}\text { Yes } \\
\text { No }\end{array}$} & \multicolumn{2}{|l|}{$\begin{array}{l}40 \% \\
60 \% \\
\end{array}$} & & \\
\hline & 11 & \multicolumn{2}{|c|}{$\begin{array}{l}\text { Yes } \\
\text { No }\end{array}$} & \multicolumn{2}{|l|}{$\begin{array}{l}90 \% \\
19 \% \\
\end{array}$} & & \\
\hline & 12 & \multicolumn{2}{|c|}{$\begin{array}{l}\text { Always } \\
\text { Sometimes }\end{array}$} & \multicolumn{2}{|l|}{$\begin{array}{l}90 \% \\
10 \%\end{array}$} & & \\
\hline & \multirow[t]{12}{*}{13} & Mobile device app & $\begin{array}{l}\text { Its } \\
\text { existence } \\
\end{array}$ & \multicolumn{3}{|c|}{ Frequency of its use } & \\
\hline & & & & Always & sometimes & Never & \\
\hline & & Google translate & $100 \%$ & $100 \%$ & & & \\
\hline & & English dictionary & $70 \%$ & $60 \%$ & $10 \%$ & $30 \%$ & \\
\hline & & Share it & $100 \%$ & $100 \%$ & & & \\
\hline & & GPS & $80 \%$ & $10 \%$ & $\mathbf{7 0 \%}$ & $20 \%$ & \\
\hline & & Voice recorder & $100 \%$ & $70 \%$ & $20 \%$ & $10 \%$ & \\
\hline & & Web browser & $100 \%$ & $90 \%$ & $10 \%$ & - & \\
\hline & & Video player & $100 \%$ & $90 \%$ & $10 \%$ & - & \\
\hline & & Video downloader & $100 \%$ & $70 \%$ & $20 \%$ & - & \\
\hline & & Image viewer & $100 \%$ & $70 \%$ & $20 \%$ & - & \\
\hline & & Face book & $90 \%$ & $80 \%$ & $10 \%$ & $10 \%$ & \\
\hline \multicolumn{8}{|l|}{$\begin{array}{l}\text { Personal } \\
\text { preferences }\end{array}$} \\
\hline & 4 & \multicolumn{2}{|c|}{ Yes } & \multicolumn{2}{|l|}{$100 \%$} & & \\
\hline & 5 & \multicolumn{2}{|c|}{$\begin{array}{l}\text { Communication } \\
\text { Education } \\
\text { Entertainment } \\
\end{array}$} & \multicolumn{2}{|l|}{$\begin{array}{c}100 \% \\
60 \% \\
80 \% \\
\end{array}$} & & \\
\hline & 9 & \multicolumn{2}{|c|}{ Yes } & \multicolumn{2}{|l|}{$100 \%$} & & \\
\hline & 14 & \multicolumn{2}{|c|}{$\begin{array}{l}\text { Yes } \\
\text { No }\end{array}$} & \multicolumn{2}{|l|}{$\begin{array}{l}90 \% \\
10 \% \\
\end{array}$} & & \\
\hline \multirow[t]{8}{*}{$\begin{array}{l}\text { The level of } \\
\text { using mobile } \\
\text { devices } \\
\text { technology }\end{array}$} & & & & & & & \\
\hline & 6 & \multicolumn{2}{|c|}{$\begin{array}{l}\text { Always } \\
\text { Sometimes } \\
\text { Never }\end{array}$} & \multicolumn{2}{|l|}{$\begin{array}{l}60 \% \\
30 \% \\
10 \% \\
\end{array}$} & & \\
\hline & 7 & \multicolumn{2}{|c|}{$\begin{array}{l}\text { Always } \\
\text { Sometimes }\end{array}$} & $\begin{array}{l}80 \% \\
20 \% \\
\end{array}$ & & & \\
\hline & 8 & & $\begin{array}{l}\text { ays } \\
\text { y when needed }\end{array}$ & $\begin{array}{l}90 \% \\
10 \% \\
\end{array}$ & & & \\
\hline & 15 & & $\begin{array}{l}\text { ays } \\
\text { etimes }\end{array}$ & $\begin{array}{l}60 \% \\
40 \% \\
\end{array}$ & & & \\
\hline & 16 & & & $\begin{array}{l}80 \% \\
20 \% \\
\end{array}$ & & & \\
\hline & 17 & & $\begin{array}{l}\text { nce } \\
\text { hnology } \\
\text { guages } \\
\text { rts } \\
\end{array}$ & $\begin{array}{l}20 \% \\
30 \% \\
40 \% \\
10 \% \\
\end{array}$ & & & \\
\hline & 18 & & tube & $100 \%$ & & & \\
\hline
\end{tabular}


English conversation, ensure equality of the students in the experimental and control groups through piloting and measure the degree of improvement of the students in both groups on English conversation after the course is over.

- Construction of the test:

It consists of two sections: "Academic knowledge" and "Use". The Academic section includes 44 items and the use section includes 31 items with the total number of 75 items for the whole test. It is constructed according to a table of specification on the basis of the conversation topics of the suggested program. Items are of the multiple- choice type. One point is given for each test item. The maximum score of this test is 75 .

- Testing time:

In piloting the test, time taken by each student was recorded, divided by the whole number of students who took the test and found to be 130 minutes. Thus, the testing time was 130 minutes.

- Instructions of the test:

They are written in English. They are brief and easy to understand. They include information about the purpose of the test, the way of recording the answers and the time allowed to complete the test.

- Validity of the test:

1- The face validity of the test was determined by submitting it to a jury of 8 TEFL experts to judge its validity according to the following criteria: linguistic stating of items, how far the items measure the objectives of the program and suitability of items for the subjects. The suggestions and recommendations of the jury members were taken into consideration and the test was revised to reach its final form.

\section{0}


2- Pearson correlation formula was used to determine the internal consistency of the test. 60 second- year English majors were selected randomly to take the test. the internal consistency of each item was calculated. The internal consistency of the individual items of both section one (academic knowledge) and two (use) was calculated as shown in table no. (2) and no. (3). The correlation between the two sections of the test and the total test was determined as shown in table no. (4). The values of the correlation coefficient are considered acceptable.

Table (2) The Internal Consistency of the individual items of section one (Academic Knowledge) and the total of section one

\begin{tabular}{c|c|c|c}
\hline Item no. & Internal consistency & Item no. & Internal consistency \\
\hline 1 & $.456^{* *}$ & 17 & $.456^{* *}$ \\
\hline 2 & $.506^{* *}$ & 18 & $.502^{* *}$ \\
\hline 3 & $.476^{* *}$ & 19 & $.423^{* *}$ \\
\hline 4 & $.450^{* *}$ & 20 & $.475^{* *}$ \\
\hline 5 & $.426^{* *}$ & 21 & $.482^{* *}$ \\
\hline 6 & $.520^{* *}$ & 22 & $.459^{* *}$ \\
\hline 7 & $.342^{* *}$ & 23 & $.477^{* *}$ \\
\hline 8 & $.519^{* *}$ & 24 & $.459^{* *}$ \\
\hline 9 & $.468^{* *}$ & 25 & $.412^{* *}$ \\
\hline 10 & $.449^{* *}$ & 26 & $.479^{* *}$ \\
\hline 11 & $.455^{* *}$ & 27 & $.470^{* *}$ \\
\hline 12 & $.489^{* *}$ & 28 & $.457^{* *}$ \\
\hline 13 & $.488^{* *}$ & 29 & $.477^{* *}$ \\
\hline 14 & $.506^{* *}$ & 30 & $.401^{* *}$ \\
\hline 15 & $.499^{* *}$ & 31 & $.427^{* *}$ \\
\hline 16 & $.561^{* *}$ & & \\
\hline
\end{tabular}

**. Correlation is significant at the 0.01 level (2-tailed).

*. Correlation is significant at the 0.05 level (2-tailed).

\section{1}


Table (3)The Internal Consistency of the individual items of section two (Use) and the total of section two

\begin{tabular}{c|c|c|c}
\hline Item no. & Internal consistency & Item no. & Internal consistency \\
\hline 1 & $.365^{* *}$ & 23 & $.409^{* *}$ \\
\hline 2 & $.497^{* *}$ & 24 & $.463^{* *}$ \\
\hline 3 & $.513^{* *}$ & 25 & $.411^{* *}$ \\
\hline 4 & $.520^{* *}$ & 26 & $.335^{* *}$ \\
\hline 5 & $.470^{* *}$ & 27 & $.478^{* *}$ \\
\hline 6 & $.419^{* *}$ & 28 & $.333^{* *}$ \\
\hline 7 & $.481^{* *}$ & 29 & $.483^{* *}$ \\
\hline 8 & $.491^{* *}$ & 30 & $.405^{* *}$ \\
\hline 9 & $.412^{* *}$ & 31 & $.362^{* *}$ \\
\hline 10 & $.460^{* *}$ & 32 & $.373^{* *}$ \\
\hline 11 & $.397^{*}$ & 33 & $.427^{* *}$ \\
\hline 12 & $.323^{*}$ & 34 & $.340^{* *}$ \\
\hline 13 & $.416^{* *}$ & 35 & $.358^{* *}$ \\
\hline 14 & $.412^{* *}$ & 36 & $.336^{* *}$ \\
\hline 15 & $.534^{* *}$ & 37 & $.420^{* *}$ \\
\hline 16 & $.319^{*}$ & 38 & $.493^{* *}$ \\
\hline 17 & $.511^{*}$ & 39 & $.431^{* *}$ \\
\hline 18 & $.309^{*}$ & 40 & $.441^{* *}$ \\
\hline 19 & $.410^{* *}$ & 41 & $.301^{*}$ \\
\hline 20 & $.414^{* *}$ & 42 & $.324^{*}$ \\
\hline 21 & $.481^{* *}$ & 43 & $.350^{* *}$ \\
\hline 22 & $.449^{* *}$ & 44 & $.381^{* *}$ \\
\hline
\end{tabular}

**. Correlation is significant at the 0.01 level (2-tailed).

*. Correlation is significant at the 0.05 level (2-tailed).

Table no (4)The correlation of the total of each section with the total of the two sections of the test

\begin{tabular}{c|c}
\hline Item no. & Internal consistency \\
\hline The total of section one & $.829^{* *}$ \\
\hline The total of section two & $.901^{* *}$ \\
\hline
\end{tabular}

**. Correlation is significant at the 0.01 level (2-tailed).

- Reliability of the test:

Establishing the reliability of the test was done during piloting. 60 second year English majors were randomly selected to take the test. The reliability coefficient of the test was determined using: (a) split-half method as Guttman Split-Half Coefficient of the test is 0.739, (b) Alpha Cronbach $(\alpha)$ coefficient which is (0.916). Cohen et al. (2007:506) point out that the split half coefficient and the alpha coefficient are considered reliable if they range from

\section{2}

Journal of Arabic Studies in Education \& Psychology(ASEP) 
0.70 to 0.90 . Thus, both of the reliability coefficients of the test are considered within the acceptable range. This is shown in table (5).

Table (5)The Cronpach Alpha's Reliability coefficient of the Test:

\begin{tabular}{c|c|c|c|c|c}
\hline Section & Mean & Variance & $\begin{array}{c}\text { Standard } \\
\text { Deviation }\end{array}$ & $\begin{array}{c}\text { No. of } \\
\text { items }\end{array}$ & Alpha \\
\hline A. Use & 20.16 & 48.189 & 6.942 & 31 & $0,884^{*}$ \\
\hline $\begin{array}{c}\text { B. Academic } \\
\text { knowledge }\end{array}$ & 27.16 & 82.015 & 9.056 & 44 & $0.95^{*}$ \\
\hline Total & 46.91 & 180.303 & 13.428 & 75 & $0.916^{*}$ \\
\hline
\end{tabular}

*. Correlation is significant at the 0.05 level.

\section{3-_A scale of autonomy}

- Objectives of the scale:

A scale of autonomy was designed by the researcher for second year English majors to measure their learning autonomy, ensure equality of the students in the experimental and control groups through piloting and assess the degree of improvement in both groups on autonomy after the course is over.

- Construction of the scale:

It is constructed on the basis of Likert three-point scale. The autonomy component is represented in the scale through a group of seven dimensions under which a group of statements are developed for measuring students' autonomy with the total number of 36 statements. 35 statements are classified as being positive while one statement only (no.4) is reverse coded as it contradicts with the term " autonomy". Each statement has three response categories rating as follows: yes, no idea and no. Responses are given scores (weights) according to the scale points as follows: Yes (3), no idea (2), no (1). There are no correct or wrong answers. Maximum score on the scale of autonomy is 106.

- Testing time:

In piloting the scale, time taken by each student was recorded, divided by the whole number of students who

\section{3}


took the scale and found to be 40 minutes. Thus, the testing time was 40 minutes.

- Instructions of the scale:

They are written in English. They are easy to understand. They include information about the purpose of the scale, its dimensions, the distribution of the scores on the points of the scale and the way of recording the answer.

- Validity of the scale:

1- The face validity of the scale was determined by submitting it to a jury of 8 TEFL experts to judge its validity according to the following criteria: linguistic stating of statements, relatedness of the statements to the components of autonomy and suitability of the statements to the subjects. The suggestions and recommendations of the jury members were taken into consideration and the scale was revised to reach its final form.

2- Pearson correlation was used to determine the internal consistency of the scale. 60 second-year English majors were randomly selected to take the scale. The internal consistency of each statement was calculated. The internal consistency of the individual statements of the dimensions of the scale was calculated as shown in table no. (6). The correlation between the seven dimensions of the scale and the total scale was determined as shown in table no. (7). The values of the correlation coefficient are considered acceptable.

3- Reliability of the scale:

Establishing the reliability of the scale was done during piloting. 60 second year English majors were randomly selected to take the scale. The reliability coefficient of the scale was determined using: (a) split-half method as Guttman Split-Half Coefficient of the scale is 0.901,

\section{4}


(b)Alpha Cronbach $(\alpha)$ coefficient which is (0.905). Both of the reliability coefficients of the scale are considered within the acceptable range. This is shown in table (8)

Table (6)The internal consistency of the statements of the autonomy scale

\begin{tabular}{c|c|c|c|c|c}
\hline Item no. & $\begin{array}{c}\text { Internal } \\
\text { consistency }\end{array}$ & Item no. & $\begin{array}{c}\text { Internal } \\
\text { consistency }\end{array}$ & Item no. & $\begin{array}{c}\text { Internal } \\
\text { consistency }\end{array}$ \\
\hline 1 & $.808^{* *}$ & 13 & $.582^{* *}$ & 25 & $.408^{* *}$ \\
\hline 2 & $.554^{* *}$ & 14 & $.549^{* *}$ & 26 & $.743^{* *}$ \\
\hline 3 & $.755^{* *}$ & 15 & $.448^{* *}$ & 27 & $.729^{* *}$ \\
\hline 4 & $.811^{* *}$ & 16 & $.483^{* *}$ & 28 & $.747^{* *}$ \\
\hline 5 & $.747^{* *}$ & 17 & $.460^{* *}$ & 29 & $.700^{* *}$ \\
\hline 6 & $.753^{* *}$ & 18 & $.552^{* *}$ & 30 & $.642^{* *}$ \\
\hline 7 & $.625^{* *}$ & 19 & $.547^{* *}$ & 31 & $.755^{* *}$ \\
\hline 8 & $.777^{* *}$ & 20 & $.701^{* *}$ & 32 & $.707^{* *}$ \\
\hline 9 & $.827^{*}$ & 21 & $.429^{* *}$ & 33 & $.832^{* *}$ \\
\hline 10 & $.674^{* *}$ & 22 & $.667^{* *}$ & 34 & $.706^{* *}$ \\
\hline 11 & $.599^{* *}$ & 23 & $.489^{* *}$ & 35 & $.775^{* *}$ \\
\hline 12 & $.570^{* *}$ & 24 & $.515^{* *}$ & 36 & $.829^{* *}$ \\
\hline
\end{tabular}

**. Correlation is significant at the 0.01 level (2-tailed).

*. Correlation is significant at the 0.05 level (2-tailed).

Table no. (7)The correlation between each dimension and the total autonomy scale

\begin{tabular}{c|c|c}
\hline Dimensions & No. of items & Internal consistency \\
\hline Independence & 4 & $.692^{* *}$ \\
\hline Decision making & 4 & $.825^{* *}$ \\
\hline Motivation & 6 & $.754^{* *}$ \\
\hline Involvement & 11 & $.885^{* *}$ \\
\hline Efficacy & 4 & $.600^{* *}$ \\
\hline Political aspects & 4 & $.659^{* *}$ \\
\hline (MALL) & 3 & $.652^{* *}$ \\
\hline
\end{tabular}

**. Correlation is significant at the 0.01 level (2-tailed).

*. Correlation is significant at the 0.05 level (2-tailed).

Table (8)The Cronpach Alpha's Reliability coefficient of the Scale:

\begin{tabular}{|c|c|c|c|c|c|c|}
\hline & Domains & Mean & Variance & $\begin{array}{l}\text { Standard } \\
\text { Deviation }\end{array}$ & $\begin{array}{l}\text { No. of } \\
\text { items }\end{array}$ & Alpha \\
\hline $1-$ & Independence & 9.18 & 4.593 & 2.143 & 4 & $0.721 *$ \\
\hline 2 & $\begin{array}{l}\text { Decision } \\
\text { making }\end{array}$ & 10.23 & 3.233 & 1.798 & 4 & $0.703 *$ \\
\hline $3-$ & Motivation & 15.67 & 4.328 & 2.080 & 6 & $0.704^{*}$ \\
\hline $4-$ & Involvement & 29.63 & 6.406 & 2.531 & 11 & $0.704 *$ \\
\hline $5-$ & Efficacy & 10.62 & 1.901 & 1.379 & 4 & $0.706^{*}$ \\
\hline $6-$ & $\begin{array}{l}\text { Political } \\
\text { aspects }\end{array}$ & 10.58 & 2.076 & 1.441 & 4 & $0.725^{*}$ \\
\hline $7-$ & MALL & 7.54 & 1.390 & 1.179 & 3 & $0.713 *$ \\
\hline & otal & 93.67 & 84.329 & 9.183 & 36 & $0.905^{*}$ \\
\hline
\end{tabular}

*. Correlation is significant at the 0.05 level. 


\section{Findings}

\section{- Hypothesis 1}

The first hypothesis of the study predicted that there was a statistically significant difference (favoring the experimental group) between means of scores obtained by the students of the experimental and control group on the post-performance of the test of conversational academic acquisition. Statistical analysis of the obtained data showed that the experimental group achieved a higher degree of improvement than the control group on the test of conversational academic acquisition as t-value (11.342) is significant at (0.001) level and beyond. Thus, the first hypothesis is confirmed. Table (9) below shows the data obtained to test this hypothesis.

Table (9) Means, Standard deviation, mean difference, $t$ value, $\eta 2$ and effect size on the post-performance of both the experimental and control group of the conversational academic acquisition test.

\begin{tabular}{|c|c|c|c|c|c|c|c|c|c|c|}
\hline $\begin{array}{l}\text { Aspects of } \\
\text { comparison }\end{array}$ & Group & No & Mean & $\begin{array}{l}\text { Mean } \\
\text { diff. }\end{array}$ & $\begin{array}{c}\text { Std. } \\
\text { Deviation }\end{array}$ & t-value & Df & $\begin{array}{l}\text { Sig. } \\
(2- \\
\text { tailed) }\end{array}$ & $\eta 2$ & $\begin{array}{l}\text { Effect } \\
\text { size }\end{array}$ \\
\hline \multirow[t]{2}{*}{$\begin{array}{c}\text { Academic } \\
\text { knowledge }\end{array}$} & $\begin{array}{l}\text { Post- } \\
\text { exp. }\end{array}$ & 30 & 24.80 & \multirow[t]{2}{*}{4.967} & 2.369 & \multirow[t]{2}{*}{7.024} & \multirow[t]{2}{*}{58} & \multirow[t]{2}{*}{0.000} & \multirow[t]{2}{*}{0.4596} & \multirow[t]{2}{*}{ Large } \\
\hline & $\begin{array}{l}\text { Post- } \\
\text { con. }\end{array}$ & 30 & 19.83 & & 3.064 & & & & & \\
\hline \multirow[t]{2}{*}{ Use } & $\begin{array}{l}\text { Post- } \\
\text { exp. }\end{array}$ & 30 & 41.07 & \multirow[t]{2}{*}{10.667} & 1.639 & \multirow[t]{2}{*}{11.390} & \multirow[t]{2}{*}{35.507} & \multirow[t]{2}{*}{0.000} & \multirow[t]{2}{*}{0.6910} & \multirow[t]{2}{*}{ Large } \\
\hline & $\begin{array}{l}\text { Post- } \\
\text { con. }\end{array}$ & 30 & 30.40 & & 4.861 & & & & & \\
\hline \multirow[t]{2}{*}{$\begin{array}{l}\text { Total of the } \\
\text { two sections }\end{array}$} & $\begin{array}{l}\text { Post- } \\
\text { exp. }\end{array}$ & 30 & 65.87 & \multirow[t]{2}{*}{15.633} & 2.751 & \multirow[t]{2}{*}{11.342} & \multirow[t]{2}{*}{37.677} & \multirow[t]{2}{*}{0.000} & \multirow[t]{2}{*}{0.6892} & \multirow[t]{2}{*}{ Large } \\
\hline & $\begin{array}{l}\text { Post- } \\
\text { con. }\end{array}$ & 30 & 50.23 & & 7.030 & & & & & \\
\hline
\end{tabular}

To ensure the effectiveness of the MALL-based program in improving students' conversational academic acquisition, eta-squared formula statistics ( $\eta 2$ ) was used. Cohen (1988) pointed out that when eta-squared value is less than 0.1 , the effect is considered weak, when it is more than 0.1 and less than 0.6 the effect is medium, and when it is more than 0.6 the effect is large. As shown in table (9) eta-squared value $((\eta 2)$ equals $(0.6892)$ which is considered large. Thus, MALL- based program is considered with high effect in

\section{6}


improving second- year English majors' conversational academic acquisition.

Additionally, the comparison of the scores obtained by the students of both the experimental and control groups on the pe-post test of conversational academic acquisition showed that the experimental group surpassed the control group as tvalue (18.497) is significant at 0.001 level. Though the results showed that the control group achieved some improvement in the post- performance of the test, this is due to being instructed the same topics in their conversation course. However, the improvement of the experimental group was larger as eta-squared value $((\eta 2)$ for the experimental group equals (0.9219) which is considered high and greater than the eta-squared value $((\eta 2)$ for the control group which equals (0.5006). Thus, MALL-based program is considered better than the conventional ways of teaching in improving learners' conversational academic acquisition. This is shown in table no. (10).

Table (10)Means, Standard Deviation, $t$ value, $\eta 2$ and effect size between mean scores of the experimental and the control group on the Pre-Post performance of the conversational academic acquisition test. $N=30$

\begin{tabular}{|c|c|c|c|c|c|c|c|c|c|}
\hline $\begin{array}{l}\text { Aspects of } \\
\text { comparison }\end{array}$ & Group & $\begin{array}{l}\text { Mea } \\
n\end{array}$ & $\begin{array}{l}\text { Mean } \\
\text { diff. }\end{array}$ & $\begin{array}{l}\text { Stand. } \\
\text { Dev. }\end{array}$ & t-value & $\mathrm{df}$ & $\begin{array}{c}\text { Sig. } \\
\text { (2-tailed) }\end{array}$ & $\eta 2$ & $\begin{array}{c}\text { Effect } \\
\text { size }\end{array}$ \\
\hline \multirow{4}{*}{$\begin{array}{c}\text { Academic } \\
\text { knowledge }\end{array}$} & Pre-exp. & 14.10 & \multirow{2}{*}{-10.700} & 3.791 & \multirow[t]{2}{*}{-12.860} & \multirow[t]{2}{*}{29} & \multirow[t]{2}{*}{0.000} & \multirow[t]{2}{*}{0.8508} & \multirow[t]{2}{*}{ Large } \\
\hline & Post-exp. & 24.80 & & 2.369 & & & & & \\
\hline & Pre-con. & 14.33 & \multirow[t]{2}{*}{-5.500} & 2.397 & \multirow[t]{2}{*}{-7.535} & \multirow[t]{2}{*}{29} & \multirow[t]{2}{*}{0.000} & \multirow[t]{2}{*}{0.6619} & \multirow[t]{2}{*}{ Large } \\
\hline & Post-con. & 19.83 & & 3.064 & & & & & \\
\hline \multirow[t]{4}{*}{ Use } & Pre-exp. & 26.80 & \multirow[t]{2}{*}{-14.267} & 4.723 & \multirow[t]{2}{*}{-16.984} & \multirow[t]{2}{*}{29} & \multirow[t]{2}{*}{0.000} & \multirow[t]{2}{*}{0.9086} & \multirow[t]{2}{*}{ Large } \\
\hline & Post-exp. & 41.07 & & 1.639 & & & & & \\
\hline & Pre-con. & 27.93 & \multirow[t]{2}{*}{-2.467} & 4.051 & \multirow[t]{2}{*}{-2.210} & \multirow[t]{2}{*}{29} & \multirow[t]{2}{*}{0.035} & \multirow[t]{2}{*}{0.1441} & \multirow[t]{2}{*}{ Large } \\
\hline & Post-con. & 30.40 & & 4.861 & & & & & \\
\hline \multirow{4}{*}{$\begin{array}{l}\text { Total of the } \\
\text { two sections }\end{array}$} & Pre-exp. & 40.90 & \multirow[t]{2}{*}{-24.967} & 7.039 & \multirow[t]{2}{*}{-18.497} & \multirow[t]{2}{*}{29} & \multirow[t]{2}{*}{0.000} & \multirow[t]{2}{*}{0.9219} & \multirow[t]{2}{*}{ Large } \\
\hline & Post-exp. & 65.87 & & 2.751 & & & & & \\
\hline & Pre-con. & 42.27 & \multirow[t]{2}{*}{-7.967} & 4.989 & \multirow[t]{2}{*}{-5.392} & \multirow[t]{2}{*}{29} & \multirow[t]{2}{*}{0.000} & \multirow[t]{2}{*}{0.5006} & Large \\
\hline & Post-con. & 50.23 & & 7.030 & & & & & \\
\hline
\end{tabular}

\section{- Hypothesis 2}

The second hypothesis of the study predicted that there was a statistically significant difference (favoring the experimental group) between means of scores obtained by the students of the experimental and control group on the 
post-performance of the scale of autonomy. Statistical analysis of the obtained data showed that the experimental group achieved a higher degree of improvement than the control group on the scale of autonomy as t-value (10.182) is significant at (0.001) level and beyond. Thus, the second hypothesis is confirmed. Table (11) below shows the data obtained to test this hypothesis.

Table (11)Means, Standard Deviation, $t$ value, $\eta 2$ and effect size on the post-performance of both the experimental and control group of the autonomy scale.

\begin{tabular}{|c|c|c|c|c|c|c|c|c|c|}
\hline $\begin{array}{l}\text { Aspects of } \\
\text { comparison }\end{array}$ & Group & No. & Mean & $\begin{array}{c}\text { Std. } \\
\text { Deviation }\end{array}$ & t-value & $\mathrm{df}$ & $\begin{array}{c}\text { Sig. } \\
(2- \\
\text { tailed) }\end{array}$ & $\eta 2$ & $\begin{array}{l}\text { Effect } \\
\text { size }\end{array}$ \\
\hline \multirow[t]{2}{*}{ Independence } & Post-exp. & 30 & 10.13 & 0.346 & \multirow[t]{2}{*}{8.508} & \multirow[t]{2}{*}{33.179} & \multirow[t]{2}{*}{0.000} & \multirow[t]{2}{*}{0.5552} & Large \\
\hline & Post-con. & 30 & 8.07 & 1.285 & & & & & \\
\hline \multirow{2}{*}{$\begin{array}{c}\text { Decision } \\
\text { making }\end{array}$} & Post-exp. & 30 & 11.70 & 0.596 & \multirow[t]{2}{*}{7.984} & \multirow[t]{2}{*}{35.109} & \multirow[t]{2}{*}{0.000} & \multirow[t]{2}{*}{0.5236} & Large \\
\hline & Post-con. & 30 & 8.90 & 1.826 & & & & & \\
\hline \multirow[t]{2}{*}{ Motivation } & Post-exp. & 30 & 17.33 & 0.959 & \multirow[t]{2}{*}{6.928} & \multirow[t]{2}{*}{43.975} & \multirow[t]{2}{*}{0.000} & \multirow[t]{2}{*}{0.4528} & Large \\
\hline & Post-con. & 30 & 14.73 & 1.818 & & & & & \\
\hline \multirow[t]{2}{*}{ Involvement } & Post-exp. & 30 & 30.70 & 2.806 & \multirow[t]{2}{*}{4.971} & \multirow[t]{2}{*}{52.584} & \multirow[t]{2}{*}{0.000} & \multirow[t]{2}{*}{0.2988} & Large \\
\hline & Post-con. & 30 & 27.57 & 2.012 & & & & & \\
\hline \multirow[t]{2}{*}{ Efficacy } & Post-exp. & 30 & 11.77 & 0.430 & \multirow[t]{2}{*}{7.203} & \multirow[t]{2}{*}{35.281} & \multirow[t]{2}{*}{0.000} & \multirow[t]{2}{*}{0.4722} & Large \\
\hline & Post-con. & 30 & 9.97 & 1.299 & & & & & \\
\hline \multirow{2}{*}{$\begin{array}{l}\text { Political } \\
\text { aspects }\end{array}$} & Post-exp. & 30 & 10.90 & 1.583 & \multirow[t]{2}{*}{3.742} & \multirow[t]{2}{*}{58} & \multirow[t]{2}{*}{0.000} & \multirow[t]{2}{*}{0.1945} & Large \\
\hline & Post-con. & 30 & 9.63 & 0.964 & & & & & \\
\hline \multirow[t]{2}{*}{ MALL } & Post-exp. & 30 & 9.00 & 0.000 & \multirow[t]{2}{*}{8.146} & \multirow[t]{2}{*}{29.000} & \multirow[t]{2}{*}{0.000} & \multirow[t]{2}{*}{0.5336} & Large \\
\hline & Post-con. & 30 & 7.50 & 1.009 & & & & & \\
\hline \multirow{2}{*}{$\begin{array}{c}\text { Total of } \\
\text { dimensions }\end{array}$} & Post-exp. & 30 & 101.53 & 4.100 & 10.182 & 46.587 & 0.000 & 0.6413 & Large \\
\hline & Post-con. & 30 & 86.37 & 7.054 & & & & & \\
\hline
\end{tabular}

To ensure the effectiveness of the MALL-based program in improving students' autonomy, eta-squared formula statistics ( $\eta 2)$ was used. As shown in table (11) eta-squared value $((\eta 2)$ equals $(0.6413)$ which is considered large. Thus, MALL- based program is considered with high effect in improving second-year English majors' learning autonomy.

Additionally, the comparison of the scores obtained by the students of both the experimental and control groups on the pe-post scale of autonomy showed that the experimental group surpassed the control group as t- value (27.666) is significant at (0.001) level and beyond. Eta-squared value $(\eta 2)$ equals (0.9635) which is considered large. Though the results showed that the control group achieved 
some improvement in the post- performance of the scale, this is due to being more aware of their responsibilities as language learners. However, the improvement of the experimental group was larger as eta-squared value $((\eta 2)$ for the experimental group equals $(0.9635)$ which is considered high and greater than the eta-squared value $((\eta 2)$ for the control group which equals (0.8482). Thus, MALL-based program is considered better than the conventional ways of teaching in improving learners' autonomy. This is shown in table no. (12).

Table (12):Means, Standard Deviation, $t$ value, $\eta 2$ and effect size between mean scores of the experimental and the control group on the Pre-Post performance of the autonomy scale. $N=30$

\begin{tabular}{|c|c|c|c|c|c|c|c|c|c|}
\hline $\begin{array}{r}\text { Aspects of } \\
\text { comparison }\end{array}$ & Group & Mean & $\begin{array}{r}\text { Mean } \\
\text { diff. }\end{array}$ & $\begin{array}{r}\text { Stand. } \\
\text { Dev. }\end{array}$ & t-value & df & $\begin{array}{r}\text { Sig. } \\
\text { (2-tailed) } \\
\end{array}$ & $\eta 2$ & $\begin{array}{r}\text { Effect } \\
\text { size }\end{array}$ \\
\hline \multirow[t]{4}{*}{ Independence } & Pre-exp. & 7.93 & \multirow[t]{2}{*}{-2.200} & 1.285 & \multirow[t]{2}{*}{-9.104} & \multirow[t]{2}{*}{29} & \multirow[t]{2}{*}{0.000} & \multirow[t]{2}{*}{0.7408} & \multirow[t]{2}{*}{ Large } \\
\hline & Post-exp. & 10.13 & & 0.346 & & & & & \\
\hline & Pre-con. & 8.07 & \multirow[t]{2}{*}{0.000} & 1.596 & \multirow[t]{2}{*}{0.000} & \multirow[t]{2}{*}{29} & \multirow[t]{2}{*}{1.000} & \multirow[t]{2}{*}{0.0000} & \multirow[t]{2}{*}{ Small } \\
\hline & Post-con. & 8.07 & & 1.285 & & & & & \\
\hline \multirow[t]{4}{*}{ Decision making } & Pre-exp. & 8.70 & \multirow[t]{2}{*}{-3.000} & 1.579 & \multirow[t]{2}{*}{-10.150} & \multirow[t]{2}{*}{29} & \multirow[t]{2}{*}{0.000} & \multirow[t]{2}{*}{0.7803} & \multirow[t]{2}{*}{ Large } \\
\hline & Post-exp. & 11.70 & & 0.596 & & & & & \\
\hline & Pre-con. & 8.83 & \multirow[t]{2}{*}{-0.067} & 1.533 & \multirow[t]{2}{*}{-0.188} & \multirow[t]{2}{*}{29} & \multirow[t]{2}{*}{0.852} & \multirow[t]{2}{*}{0.0012} & \multirow[t]{2}{*}{ Small } \\
\hline & Post-con. & 8.90 & & 1.826 & & & & & \\
\hline \multirow[t]{4}{*}{ Motivation } & Pre-exp. & 11.33 & \multirow[t]{2}{*}{-6.000} & 1.647 & -18.254 & 29 & 0.000 & 0.9199 & Large \\
\hline & Post-exp. & 17.33 & & 0.959 & & & & & \\
\hline & Pre-con. & 11.23 & -3.500 & 1.569 & -11.036 & 29 & 0.000 & 0.8077 & Large \\
\hline & Post-con. & 14.73 & & 1.818 & & & & & \\
\hline Involvement & Pre-exp. & 20.80 & -9.900 & 3.199 & -10.938 & 29 & 0.000 & 0.8049 & Large \\
\hline & Post-exp. & 30.70 & & 2.806 & & & & & \\
\hline & Pre-con. & 20.63 & -6.933 & 3.189 & -14.184 & 29 & 0.000 & 0.8740 & Large \\
\hline & Post-con. & 27.57 & & 2.012 & & & & & \\
\hline Efficacy & Pre-exp. & 8.17 & -3.600 & 2.167 & -9.065 & 29 & 0.000 & 0.7391 & Large \\
\hline & Post-exp. & 11.77 & & 0.430 & & & & & \\
\hline & Pre-con. & 8.27 & -1.700 & 1.721 & -4.264 & 29 & 0.000 & 0.3854 & Large \\
\hline & Post-con. & 9.97 & & 1.299 & & & & & \\
\hline Political aspects & Pre-exp. & 6.80 & -4.100 & 1.400 & -12.560 & 29 & 0.000 & 0.8447 & Large \\
\hline & Post-exp. & 10.90 & & 1.583 & & & & & \\
\hline & Pre-con. & 6.90 & -2.733 & 1.348 & -8.700 & 29 & 0.000 & 0.7230 & Large \\
\hline & Post-con. & 9.63 & & 0.964 & & & & & \\
\hline MALL & Pre-exp. & 5.07 & -3.933 & 0.785 & -27.447 & 29 & 0.000 & 0.9629 & Large \\
\hline & Post-exp. & 9.00 & & 0.000 & & & & & \\
\hline & Pre-con. & 5.00 & -2.500 & 0.871 & -8.721 & 29 & 0.000 & 0.7240 & Large \\
\hline & Post-con. & 7.50 & & 1.009 & & & & & \\
\hline Total of & Pre-exp. & 68.80 & -32.733 & 5.880 & -27.666 & 29 & 0.000 & 0.9635 & Large \\
\hline dimensions & Post-exp. & 101.53 & & 4.100 & & & & & \\
\hline & Pre-con. & 68.93 & -17.433 & 6.411 & -12.731 & 29 & 0.000 & 0.8482 & Large \\
\hline & Post-con. & 86.37 & & 7.054 & & & & & \\
\hline
\end{tabular}

\section{Discussion}

1- The inherent features of the study on the basis of the students' reflections 
- Generally, all the students showed their eagerness at the introductory phases of the experiment towards the use of their mobile devices for learning either inside or outside the classroom.

- Most of the students lacked knowledge as well as technical skills about the use of network resources either through their mobile devices or any other devices for academic purposes.

- Most of the students showed great interest on the videos uploaded as shown through their interaction and chat conversation on our closed Facebook account as they asked for the time of uploading, reloading, or the need to have it via sharing due to temporal lack of internet access.

- Similarly, they were highly active and collaborative inside and outside the classroom. They used to analyze and share the vocabulary and structures of the videos on their face book account. In addition, they used to watch the assigned video many times even before the session. They kept themselves busy discussing and sharing the other suggested videos for the topic.

- At nearly the middle of the program, they showed their self-dependence and understanding the technique of the program through analyzing the components of the uploaded conversations and being ready for presentation and discussion during the teaching session.

- Towards the end of the program, they started to ask about further information and resources to use them independently in their free time.

2- The interpretation of the results with reference to the related literature

- The suitable integration of technological applications in language learning and the use of mobile phones foster a high degree of learners' autonomy (Seiz- Ortiz and Romero Forteza, 2013 and Sateo et al., 2015). Similarly,

\section{0}


dedicating the responsibility of learning to learners can lead to better learning outcomes (Moghaddad \& Bashirnzad ,2016)

- Leow et al. (2014) concluded that applying the technology of mobile devices with its recording and play back function for rehearsing and retaining the verbal information through the voice-messaging technology allows the development of learners' communicative skills.

- Using the technology in language learning and teaching will direct learners towards being more autonomous, creative and motivated (Wong and Looi, 2010). Kolb $(2008,2011)$ declares that mobile phones are toys which can be used as tools for learning with joy.

3- The relation of the results of the present study to the results of other conducted studies

a- Results of studies coincides with those obtained by the present study

- The results of the study corresponded with Sharples (2005) who assured the importance of mobile phones in knowledge building. It also confirmed with Rosell Aguilar (2007), Nah, White and Sussex (2008) and Moghaddad \& Bashirnzad (2016) who stressed the affordance of the utilization of mobile-phones for language learning.

- Using the technology in language learning and teaching will direct learners towards being more autonomous, creative and motivated (Wong and Looi, 2010; Kolb, 2008, 2011 and Seiz- Ortiz and Romero Forteza, 2013). Sateo et al., 2015 declares that mobile phones are toys which can be used as tools for learning with joy.

b- Studies having results different from those obtained by the present study 
- The research is against the results of Salaberry (2001) who denied the effectiveness of mobile phones for language learning.

\section{Implications}

The adoption of mobile devices through this study has a number of implications and practical consequences for learners, learning design as well as teachers and advisors as follows:

- Learners can capture samples of their speech or writings in class through their mobile devices for reflection and feedback.

- Learners with different special needs can be aided through the features of mobile devices as screenreading, sound amplification as well as different applications that can facilitate lip-reading and sign language.

- Learners can access other online sources of the target language input on their mobile devices and may share it with their teachers and peers.

- Learners can use their mobile devices for taking photos of their work to use them for afterwards reflection.

- Learners can use resources on their mobile devices as dictionaries or translators in situations where they have communication breakdown in and outside classrooms.

\section{Recommendations}

- The notion of $21^{\text {st }}$ Century digital learners should be addressed in relation to these learners' needs together with the availability of integrating technology for facilitating their language learning process.

- MALL training opportunities should be offered to teachers to keep them acquainted with innovations in technology that support education.

- Concerning teacher training, mobile pedagogy and technology could be integrated in training courses and

\section{2}


materials to keep teachers updated and be ready for applying innovations in the domain.

- Institutions of Education, at all levels, should try some policy and infrastructure changes to enhance the use of technology resources for instructors and learners as well.

- Concerning learning theories, instructional designs and assessment techniques, several mobile applications can be suggested by technology as well as pedagogy experts.

- As for students with disabilities, new and adaptable mobile applications could be discovered.

- The stakeholders and decision makers should pursue recent instructional designs and techniques that support integrating technology in the teaching/learning process as mobile applications.

- In relation to cost effectiveness and since most of mobile technologies and applications along with social networks are free, they could substitute the daily traditional materials teachers carry to their classes. Moreover, the relative cost of using mobile devices networks in different geographical locations should be addressed.

\section{Suggestions for further research}

- MALL and individual language learning strategies

- MALL and learning styles.

- MALL and the development of individual writing process, pronunciation performance or reading comprehension.

- The impact of MALL on students' study habits on a daily or weekly basis over an entire course.

- Conducting interviews with teachers to determine the impact of using mobile devices inside the classrooms; i.e. time constraints and technical problems.

\section{3}




\section{Conclusion}

Beyond the classroom, MALL paves the way towards learning the language in terms of content delivery more than has been previously recognized. As one of the digital tools that forms a part of everyday habitual practices, mobile learning provides a great opportunity for developing technologically enhanced learning practices. (Lindaman \& Nolan, 2015). The integration of mobile phones as new frontiers for teaching and learning has led to generating a great amount of motivation and excitement among practitioners and academicians. This is due to the innovations it adds to the academic learning environment. It provided an innovative and practical settings for teachers in the developing countries like Egypt who have very limited access to the sophisticated technologies in their classes. As still a new emerging field, the scholarly literature on MALL is small and motivates the contribution of researchers.

\section{References}

Abraham. L. B.. \& Williams. L. (2011). Expanding Discourse Options Through Comnuter-Mediated Communication: Guiding Learners Toward Autonomy. Foreign Language Annals, 44(4), 626-645.

AbuSa'aleek. A. O. (2014). A review of emerging technologies: Mobile assisted language learning (MALL). Asian Journal of Education and e-Learning (ISSN: 2321-2454), 2(06).

Al Qasim, N., \& Al Fadda, H. (2013). From Call to Mall: The effectiveness of podcast on EFL higher education students' listening comprehension. English Language Teaching, 6(9), 3041.

Ally, M. (Ed.). (2009). Mobile learning. Transforming the delivery of education and training. Edmonton: AU Press.

Al-Madani, F. M., \& Allafiajiy, I. A. (2014). Teachers' Professional Development on ICT Use: A Saudi Sustainable Development Model. Journal of Modern Education Review, 4(6), 448-456. doi:10.15341/imer(2155-7993)/06.04.2014/006

Al-Zahrani. A. S. (2015). Smartnhones wandering at the mall: A case studv investigating the use of smartphones on English oral learning skills in a collaborative mobile-assisted language learning environment (Doctoral dissertation, Northern Illinois University).

\section{4}


Amer. M. A. (2010). Idiomobile for learners of English: A studv of learners' usage of a mobile learning application for learning idioms and collocations.

Angelov. P. (2012). Autonomous learning svstems: from data streams to knowledge in real-time. John Wiley \& Sons.

Appendix 1: English Version of Ouestionnaire on Learner Autonomv. (n.d.). Retrieved Jan 1. 2016. from http://bdigital.unal.edu.co/ 46871/11/41821-190675-1-SP.pdf

Ardasheva, Y., \& Tretter, T. R. (2013). Strategy Inventory for Language Learning-ELL Student Form: Testing for Factorial Validity. The Modern Language Journal, 97(2), 474-489. doi:10.1111/i.1540-4781.2013.12011.x

Autonomv. (n.d.). In Dictionarv.Cambridge.org. Retrieved from httns://dictionarv.cambridge.org/dictionarv/english/autonomv

Baleghizadeh. S.. \& Oladrostam. E. (2010). The effect of mobile assisted language learning (MALL) on grammatical accuracy of EFL students. Mextesol Journal, 34(2), 1-10.

Benson, P. (2001). Teaching and Researching Autonomy in Language Learning. Applied Linguistics in Action Series.

Bidaki, M. Z.; Naderi, F.; \& Ayati, M. (2013), Effects of Mobile Learning on Paramedical Students' Academic Achievement and Self-regulation. Future of Medical education Journal, 3(3), 2428. Retrieved from http://fmei.mums.ac.ir/article 1524 0.html

Blake. N.. Smevers. P.. Smith. R. D.. \& Standish. P. (Eds.). (2008). The Blackwell guide to the philosophy of education(Vol.

6). John Wilev \& Sons.

Bonnett. M.. \& Cuvpers. S. (2003). Autonomv and authenticitv in education. The Blackwell guide to the philosophy of education, 326-340

Bown. J. (2009). Self-regulatorv strategies and agencv in self-instructed language learning: A situated view. The Modern Language Journal, 93(4), 570-583.

Boyadzhieva, E. (2016). Learner-centered Teaching and Learner Autonomy. Procedia - Social and Behavioral Sciences, 232, 3540. doi:10.1016/j.sbspro.2016.10.008

Ceylan, N. O. (2015). Fostering Learner Autonomy. Procedia - Social and Behavioral Sciences, 199, 85-93. doi:10.1016/ j.sbspro. 2015.07.491

Chen, C-M., \& Hsu, S-H. (2008). Personalized Intelligent Mobile Learning System for Supporting Effective English Learning. Educational Technologv \& Societv. 11(3). 153-180.

Chinnerv. G. M. (2006). Emerging technologies. Going to the mall: mobile assisted language learning. Language learning \& technology, 10(1), 9-16.

Chun, D., Kern, R., \& Smith, B. (2016). Technology in Language Use, Language Teaching, and Language Learning. The Modern Language Journal, 100(S1), 64-80. doi:10.1111/modl.12302

\section{5}


Cohen, J. (1988) Statistical Power Analysis for the Behavioral Sciences. Hillsdale. N.: Erlbaum.

Cohen. L.. Manion, L., \& Morrison, K. (2007). Research methods in education.

Comas-Quinn, A., Mardomingo, R., \& Valentine, C. (2009). Mobile blogs in language learning: Making the most of informal and situated learning opportunities. ReCALL, 21(1), 96-112. http://dx.doi.org/10.1017/S0958344009000032

Communication. (n.d.). Retrieved Feb 1, 2016, from https://docs. google.com/document/d/1T7svpiLHnLzgZQ9Efk_JZgx2aUbsp RNyPgUPZUuHNJk/edit.

Cooney, G. and Keogh, K. (2007) Use of mobile phones for language learning and assessment for learning. Paper presented at MLearn 2007. http://www.learnosity.com/files/learnosity-use-ofmobilephones-for-language-learning-and-assessment-for-learning.pdf.

Cristina, T. (2015). The Teacher's Role in Building the Student' $\mathrm{S}$ Range of Autonomy. Procedia - Social and Behavioral Sciences. 203. 22-27. doi:10.1016/i.sbspro.2015.08.254

Czerska-Andrzeiewska. D. (2016). Mobile assisted language learning. Zeszyty Glottodydaktyczne, 2016 (Zeszyt 6 (2016)),4352.

De Jong. T.. Specht. M.. \& Koper. R. (2008). A reference model for mobile social software for learning. International iournal of continuing engineering education and life long learning. 18(1), 118-138. httn://dx.doi.org/10.1504/IJCEELL.2008.016079

Dos, B. (2014). The Relationshin between Mobile Phone Use. Metacognitive Awareness and Academic Achievement. European Journal of Educational Research.3(4). 192-200. Retrieved from http://files.eric.ed.gov /fulltext/ EJ1085990.pdf

El- Hussein, M. O. M., \& Cronje, J. C. (2010). Defining Mobile Learning in the Higher Education Landscape.Educational Technology \& Society, 13(3), 12-21. Retrieved from http://www.ifets.info/iournals/13 3/3.pdf

Elfekv. A. I. M.. \& Masadeh. T. S. Y. (2016). The Effect of Mobile 'Learning on Students' Achievement and Conversational Skills. International Journal of higher education, 5(3). doi: 10. 5430/ijhe.v5n3p20

Elias, T. (2011). Universal instructional design principles for mobile learning. International Review of Research in Open and Distance Learning, 12(2), 143-156. Retrieved from http://www.eric.ed.gov/PDFS/EJ920738.pdf.

Ertürk, N. O. (2016). Language Learner Autonomy: Is it Really Possible? Procedia - Social and Behavioral Sciences, 232, 650654. doi:10.1016/j.sbspro.2016.10.089

Fallahkhair, S., Pemberton, L., \& Griffiths, R. (2007). Development of a cross-platform ubiquitous language learning service via 
mobile phone and interactive television. Journal of Computer Assisted Learning, 23, 321-325.

Fomani, E., \& Hedayayi, M. (2016). A seamless learning design for mobile assisted language learning: an Iranian context. English Language Teaching, 9, 206-213.

Godwin-Jones, R. (2010). Emerging technologies from memory palaces to spacing algorithms: approaches to secondlanguage vocabulary learning. Language, Learning \& Technology, 14(2).

Godwin-Jones, R. (2011). Emerging technologies: Mobile apps for language learning. Language Learning \& Technology, 15(2), 211.

Gromik. N. A. (2012). Cell phone video recording feature as a language learning tool: A case study. Computers \& education, 58 (1), 223-230.

Guerrero, L. A., Ochoa, S., \& Collazos, C. (2010). A mobile learning tool for improving grammar skills. Procedia-Social and Behavioral Sciences, 2(2), 1735-1739.

Haddad, R. H. (2016). Developing Learner Autonomy in Vocabulary Learning in Classroom: How and Why can it be Fostered? Procedia - Social and Behavioral Sciences, 232, 784-791. doi:10.1016/j.sbspro.2016.10.106

Hazaea, A., \& Alzubi, A. (2016). The effectiveness of using mobile on EFL learners' reading practices in Narjan University. English Language Teaching. 9. 8-21.

Hoffmann. C. (2000). Language. autonomv and national identity in Catalonia. The Sociological Review, 48(1_suppl), 48-78.

Hoven, D. \& Palalas, A. (2011). (Re)-conceptualizing design approaches for mobile language learning. CALICO, 28(3), 699720. http://files.eric.ed.gov/fulltext/EJ1085990.pdf

Ivanovska, B. (2015). Learner Autonomy in Foreign Language Education and in Cultural Context. Procedia - Social and Behavioral Sciences, 180, 352-356. doi:10.1016/j. sbspro. 2015. 02.128

Jabbour. K. K. (2013). An Analvsis of the Effect of Mobile Learning on Lebanese Higher Education. Bulgarian .Journal of Science and Education Policv (B.ISEP). 7(2), 280-301. Retrieved from http://bjsep.org/getfile.php?id=145

Jee, M. J. (2011). Web 2.0 Technology meets mobile assisted language learning.International Association for Language Learning Technologv. 41(1), 161-175.

Johnson, L., Becker, S. A., \& Cummins, M. (2012). The NMC horizon report: 2012 higher education edition. Retrieved from http:// akgul.bilkent.edu.tr/nmc/2012-Horizon-Report-HE.pdf

Johnson. L.. Becker, S. A., Cummins, M., Estrada, V., Freeman, A., \& Hall, C. (2013). NMC Horizon Report: 2013 Higher Education Edition. Retrieved from http://www.cdc.qc.ca/pdf/2013Horizon-Report-creative-commons-copy.pdf

\section{7}


Kennedy, C., \& Levy, M. (2008). L'italiano al telefonino: Using SMS to support beginners' language learning. ReCALL, 20(3), 315330. httb://dx.doi.org/10.1017/S0958344008000530

Khubvari. L.. \& Narafshan. M. H. (2016). A studv on the impact of MALL (Mobile Assisted Language Learning) on EFL learners' reading commrehension. International Journal of English Language Teaching, 4(2), 58-69.

Klopfer, E., Squire, K. \& Jenkins, H. (2002). Environmental Detectives: PDAs as a window into a virtual simulated world. In Proceedings of IEEE International Workshop on Wireless and Mobile Technologies in Education (pp. 95-98). Vaxjo, Sweden: IEEE Computer Society.

Kukulska-Hulme, A. (2009). Will mobile learning change language learning? European Association for Computer Assisted Language Learning, 21(2), 157-165.

Kukulska-Hulme, A. (2012, February, 28). Mobile Learning and the Future of Learning: An HETL interview with Dr. Agnes Kukulska-Hulme. Interviewers: Krassie Petrova and Patrick Blessinger. The International HETL Review, 2, Retrieved February 5, 2016 from https://www.hetl.org/interview-articles/ mobile-learning-and-the-future-of-learning

Kukulska-Hulme, A., \& Shield, L. (2008). An overview of mobile assisted language learning: From content delivery to supported collaboration and interaction. ReCALL, 20(03). doi:10.1017/ s0958344008000335

Kukulska-Hulme. A.. Norris. L.. \& Donohue. J. (2015). Mobile pedagogy for English language teaching: a guide for teachers

Lan, Y. J., Sung, Y. T., \& Chang, K. E. (2007). A mobile-device supported peer-assisted learning system for collaborative early EFL reading. Language Learning \& Technology,11(3),130-151.

Lan, Y.-J., Sung, Y.-T., \& Chang, K.-E. (2013). From particular to popular: facilitating EFL mobilesupported cooperative reading. Language. Learning \& Technologv. 17. 23-38.

Language acauisition. (n.d.). In MacmillanDictionarv.com. Retrieved from httns://www.macmillandictionary.com/dictionary/british/ language-acauisition

Language Acauisition. (n.d.). In Allevdog.com's online glossarv. Retrieved from: httns://www.allevdog.com/glossary/definition cit.php?term=Language+Acquisition

Leis, A. (2014). Encouraging autonomy through the use of a social networking system. JALT CALL Journal IO(1), 69-80

Leis, A., Tohei, A., \& Cooke, S. D. (2015). Smartphone Assisted Language Learning and Autonomy. International Journal of Computer-Assisted Language Learning and Teaching, 5(3), 7588. doi:10.4018/iicallt.2015070105

Leow. C. K.. Yahava. W. A. J. W.. \& Samsudin. Z. (2014). MobileAssisted Second Language Learning: Developing a Learner- 
Centered Framework. International Association fo Development of the Information Society.

Levy, M., \& Kennedy, C. (2005). Learning Italian via mobile SMS. In A. KukulskaHulme \& J. Traxler (Eds.), Mobile learning: A handbook for educators and trainers (pp. 79-83). London: Routledge.

Lin, L. F. (2011). The video comprehension strategies of Chinesespeaking universitv students. Journal of Educational Computing Research, 45(3), 297-319.

Lindaman, D., \& Nolan, D. (2016). Mobile-Assisted Language Learning: Application Development projects within reach for language teachers. IALLT Journal of Language Learning Technologies, 45(1), 1-22.

Liskin-Gasparro, J. E. (2009). MLJ Reviews. 93(3), 439-470. doi:10.1111/j.1540-4781.2009.00901_1.x

Liskin-Gasparro, J. E. (2012). MLJ Reviews. 96(3), 463-4^乏. doi:10.1111/j.1540-4781.2012.01367_1.x

Lu, M. (2008). Effectiveness of vocabulary learning via mobile phone. Journal of Computer Assisted Learning, 24(6), 515-525. http://dx.doi.org/10.1111/j.1365-2729.2008.00289.x

Lyddon, P. A. (2016). Mobile-assisted language learning and language learner autonomy. In CALL communities and cultureshort papers from EUROCALL 2016 (pD. 302-306).

Martin. P. R.. Cheung. F. M.. Knowles. M. C.. Kvrios. M.. Littlefield. L.. \& Overmier. J. B. (Eds.). (2011). IAAP handbook of applied psychology. John Wiley \& Sons.

McClanahan, B., Williams, K., Kennedy, E., \& Tate, S. (2012). A Breakthrough for Josh: How Use of an iPad Facilitated Reading Improvement.TechTrends: Linking Research and Practice to Imnrove Learning. 56.20-28.

Menezes. V. (2011). Affordances for language learning bevond the classroom. In Bevond the language classroom (pp. 59-71). Palgrave Macmillan. London.

Miangah. T. M.. \& Nezarat. A. (2012). Mobile-assisted language learning. International Journal of Distributed and Parallel Systems, pp.309-319.

http://www.airccse.org/journal/ijdps/papers/0112ijdps26.pdf

Mitra, S. (2005). Self organising systems for mass computer literacy: Findings from the 'hole in the wall' experiments. International .Journal of Develonment Issues. 4(1), 71-81.

Moghaddas, B., \& Bashirnezhad, H (2016). The Pedagogical Applications of Mobile-Assisted Language Learning (MALL) in Improving the Iranian EFL Learners\&apos; Oral Performance. International Journal of Applied Linguistics and Translation, 2(1). doi:10.11648/j.ijalt.20160201.12

Mohammadi, M., \& Safdari, N. (2015). Pedagogical values of mobileassisted task-based activities to enhance speaking skill. Paper 
presented at the Critical CALL - Proceedings of the 2015 EUROCALL Conference, Padova, Italy.

Motallebzadeh, K., \& Ganjali, R. (2011). SMS: Tool for L2 Vocabulary Retention and Reading Comprehension Ability. Journal of Language Teaching and Research, 2(5), 1111-1115. http://dx.doi.org/10.4304/jltr.2.5.1111-1115

Muhammed, A. A. (2014). The impact of mobiles on language learning on the part of English foreign language (EFL) university students. Procedia-Social and Behavioral Sciences, 136, 104-108.

Nah, K., C., White, P, \& Sussex, R. (2008). \&e potential of using a mobile phone to access the Internet for learning EFL listening skills within a Korean context. ReCALL. 20 (3). 331-347.

Nenniger. P. (2011). Autonomv in Learning and Instruction: Roots. Frames. and Concents of a Basic Issue. IAAP Handbook of Applied Psvchologv. 162-184.

Nunan. D. (2003). Nine steps to learner autonomy. In Symposium (Vol. 2003, pp. 193-204).

Oberg, A., \& Daniels, P. (2012). Analysis of the effect a studentcentred mobile language learning using handhelds. International Journal of Learning Technology, 5(1), 435-449

Oga-Baldwin, W. L. Q., \& Nakata, Y. (2015). Structure also supports autonomy: Measuring and defining autonomy-supportive teaching in Japanese elementary foreign language classes. Japanese Psychological Research, 57(3), 167-179. doi:10.1111/ jpr. 12077

Ogata, H., Hui, G. L., Yin, C., Ueda, T., Oishi, Y., \& Yano, Y. (2008). LOCH: supporting mobile language learning outside classrooms. International Journal of Mobile Learning and Organisation, 2(3), 271-282. http://dx.doi.org/10.1504/ IJMLO. 2008.020319

OĞUz, A. (2013). Developing a Scale for Learner Autonomy Support. Educational Sciences: Theory \& Practice. doi:10.12738/ estp .2013 .4 .1870

Ortiz, R. S. (2015). Mobile Language Learning based on pedagogical criteria. @ tic. revista d'innovació educativa, O(15). doi:10.7203/ attic. 15.6407

Palalas, A. (2011). Mobile-assisted language learning: Designing for your students. Second language teaching and learning with technologv: views of emergent researchers, 71-94.

Petersen, S. A., \& Divitini, M. (2005). Language Learning: from Individual Learners to Communities. En VVAA. Proceedings of the third International Workshop on Wireless and Mobile Technologies in Education 2005, IEEE Computer Society Press, pp.169-173.http://www.idi.ntnu.no/grupper/su/publ/sappetersen _.wmte2005.pdf 
Petersen, S. A., Divitini, M., \& Chabert, G. (2009). Sense of community among mobile language learners: Can blogs support this? International Journal of Web Based Communities, 5(3), 428-445. http://dx.doi.org/10.1504/IJWBC.2009.025217

Porto, M. (2007). Learning diaries in the English as a foreign language classroom: A tool for accessing learners' nercentions of lessons and developing learner autonomy and reflection. Foreign Language Annals, 40(4), 672-696.

Rahimi, M., \& Soleymani, E. (2015). The impact of mobile learning on listening anxiety and listening comprehension. English Language Teaching. 8(10). 152

Reeve. J. (2011). Teaching in wavs that support students' autonomy. Enhancing teaching and learning, 90-103.

Reinders, H. \& White, C. (2010). The theory and practice of technology in materials development and task design. In Harwood, N. (Ed.) Materials in ELT: Theory and practice, (pp. 58-80). Cambridge: Cambridge University Press.

Rivers, D. (2009). Utilizing the quick response (QR) code within a Japanese EFL environment. The JALT CALL Journal, 5(2), 1528.

Robertson. L. (2009). Mobile annlication for language learning: MALL Research Project Report. Curriculum Corporation, 1-48.

Rose, H. (2013). L2 learners' attitudes toward, and use of, mnemonic strategies when learning Japanese kanji. The Modern Language Journal, 97(4), 981-992. doi:10.1111/j.1540-4781.2013.12040.x

Rosell-Aguilar, F. (2007). Top of the pods-in search of a podcasting "podagogy" for language learning, Computer Assisted Language Learning, 20(5), 471-492.

Sad, S.N. (2008). Using mobile phone technology in EFL classes. English Teaching Forum, 46(4).

Sandberg, J., Maris, M., \& de Geus, K. (2011). Mobile English learning: An evidence-based study with fifth graders. Computers \& Education, 57(1), 1334-1347.

Sanders, R. (1995). Thirty Years of Computer Assisted Language Instruction:Introduction, CALICO, 12(4).

Sato, T., Matsunuma, M., \& Suzuki, A. (2013). Enhancement of automatization through vocabulary learning using CALL: can prompt language processing lead to better comprehension in L2 reading? ReCALL, 25(1), 143-158. doi:10.1017/ S09583440 12000328

Sato, T.,Murase, F.,\& Burden,T.(2015). Is mobile-assisted language learning really useful? An examination of recall automatization and learner autonomy. Paper presented at the Critical CALL Proceedings of the 2015 EUROCALL Conference,Padova, Italy. Savignon, S. J. (2000). Communicative language teaching. In M. Byram(Ed.),Routledge Encyclopedia of Language Teaching and Learning (pp.125-129).London, England: Routledge.

\section{1}


Shah, P. M.. Puteh. S. N.. Din. R.. Rahamat. R.. \& Aziz. J. A. (2014). User needs analvsis in learning aroumentative writing via mobile platform. Procedia-Social and Behavioral Sciences, 118, 198-205.

Shams, I. E. (2013). Hybrid Learning and Iranian EFL Learners' Autonomy in Vocabulary Learning. Procedia - Social and Behavioral Sciences, 93, 1587-1592. doi:10.1016/j. sbspro. 2013.10.086

Shao, Y. (2010). Mobile group blogging in learning: a case study of supporting cultural transition. University of Nottingham.

Sharples, M. (2000). The design of personal mobile technologies for lifelong learning. Computers \& Education. 34(3-4). 177-193.

Sharples. M. (2002). Disruptive devices: mobile technologv for conversational learning. International .Journal of Continuing Engineering Education and Life Long Learning, 12(5-6), 504520.

Shih, R. C. (2013). Effect of Using Facebook to Assist English for Business Communication Course Instruction. Turkish Online Journal of Educational Technology-TOJET, 12(1), 52-59.

Sierens, E., Vansteenkiste, M., Goossens, L., Soenens, B., \& Dochy, F. (2009). The synergistic relationship of perceived autonomy support and structure in the prediction of self-regulated learning. $\mathrm{Br}_{\mathrm{J}}$ Educ Psychol, 79(Pt 1), 57-68. doi:10.1348/000709908X304398

Šimonová, I. (2015). Mobile-assisted ESP learning in technical education. Journal of Language and Cultural Education, 3(3), 1-15. doi:10.1515/iolace-2015-0016

Simpson.M. N. (2012). ESL@ Facebook: A Teacher's Diarv on Using Facebook. Teaching English with Technology, 12(3), 36-48.

Smith, P. L. \& Ragan, T. J. (2005). Instructional Design, (3rd Edition), Hoboken, NJ: Wiley.

Stockwell, G. (2008). Investigating learner preparedness for and usage patterns of mobile learning. ReCALL, 20(3), 253-270

Stockwell, G., \& Hubbard, P. (2013). Some emerging principles for mobile-assisted language learning. Monterey, CA: The International Research Foundation for English Language Education. Retrieved from http://www.tirfonline.org/english-inthe-workforce/mobile-assisted-language-learning

Sylvén, L. K., \& Sundqvist, P. (2012). Gaming as extramural English L2 learning and L2 proficiency among young learners. ReCALL, 24(03), 302-321. doi:10.1017/s095834401200016x

Sylvester, R., \& Greenidge, W. L. (2009). Digital storytelling: Extending the potential for struggling writers. The reading teacher, 63(4), 284-295.

Thornton, P., \& Houser, C. (2005). Using mobile phones in English education in Japan. Journal of Computer Assisted Learning,

\section{2}


21(3), 217-228. http://dx.doi.org/10.1111/j.1365-2729.2005. $00129 . x$

Viberg. O.. \& Grönlund. A. (2012). Mobile assisted language learning: A literature review. In 11th World Conference on Mobile and Contextual Learning.

Wang, S., \& Heffernan, N. (2009). Mobile 2.0 and Mobile Language Learning. In M. Thomas (Ed.), Handbook of Research on Web 2.0 and Second Lanquage Learning (pD. 472-490): IGI Global.

Wang. S.. \& Smith. S. (2013). Reading and grammar learning through mobile nhones. Lanquage Learning \& Technologv. 17(3).

Wang. X. (2014). Imnroving English skills through Video: A Conversation-Based Curriculum for Chinese EFL Adult Learners.

Warschauer, M. and Meskill, C. (2000). Technology and second language teaching. In J. W. Rosenthall (Ed.), Handbook of undergraduate second language education (pp. 303-318). NJ, Mahwah: Lawrence Erlbaum.

Weng T.H.,\& Chen Y.J. (2015). Students' perceptions towards the use of smartphone applications for English learning, International Journal of Educational Science and Research, 5, 1-10.

White, J., \& Mills, D. (2014). Examining attitudes towards and usage of smartphone technology among Japanese university students studving EFL. CALL-EJ. 15(2). 1-15.

Wikipedia contributors. (2016. Januarv 18). Language acauisition. In Wikinedia. The Free Encvclonedia. Retrieved 11:00. January 19.2016. from httns://en. wikinedia.org/w/index.php?title=Langu age acauisition\&oldid $=860135260$

Wilson. T. S.. \& Rvg. M. A. (2015). Becoming autonomous: Nonideal theorv and educational autonomy. Educational Theory, 65(2), 127-150.

Winet, D. (2016). Mobile Instant Messaging In the ESL Writing Class. The Electronic Journal for English as a Second Language, 20(3), 1-6.

Wishart, J. (2009). Use of mobile technology for teacher training. In M. Ally (Ed.), Mobile Learning: Transforming the Delivery of Education and Training (pp. 265-278). Edmonton, Canada: Athabasca University Press.

Wong, L. H., Chen, W., \& Jan, M. (2012). How artefacts mediate small-group co-creation activities in a mobile-assisted seamless language learning environment? Journal of Computer Assisted Learning, 28(5),411-424.doi:10.1111/j.1365-2729.2011.00445.x Yagcioglu, O. (2015). New Approaches on Learner Autonomy in Language Learning. Procedia - Social and Behavioral Sciences, 199, 428-435. doi:10.1016/j.sbspro.2015.07.529

Yang, J. (2013). Mobile Assisted Language Learning: Review of the Recent Applications of Emerging Mobile Technologies. English Language Teaching, 6(7). doi:10.5539/elt.v6n7p19

\section{3}


Yang, J., \& Park, J. (2012). Software Review: SuperMemo UXExtreme English Advanced and Proficient. CALICO Journal, 29(4). 718-726. http://dx.doi.org/10.11139/ci.29.4.718-726

Yedla. S. (2013). MALL (mobile assisted language learning): A naradise for English language learners. Journal of English Language \& Translation Studies, 1(2), 91-99.

Zhang, H., Song, W., \& Burston, J. (2011). Reexamining the effectiveness of vocabulary learning via mobile phones. TOJET, 10(3)

Zhang, Y. (2016). The Impact of Mobile Learning on ESL Listening Comprehension. DEStech Transactions on Social Science, Education and Human Science, (icaem).

Zou, B., \& Li, J. (2015). Exploring mobile apps for English language teaching and learning. In F. Helm, L. Bradley, M. Guarda, \& S. Thouësny (Eds), Critical CALL - Proceedings of the 2015 EUROCALL Conference, Padova, Italy (pp. 564-568). Dublin: Researchpublishing.net.

http://dx.doi.org/10.14705/rpnet.2015.000394

\section{潾潾潾潾潾}

\section{4}

